\title{
Nonpharmacological Therapies in Alzheimer's Disease: A Systematic Review of Efficacy
}

\author{
Javier Olazarán ${ }^{a}$ Barry Reisbergi Linda Clare e Isabel Cruz ${ }^{\mathrm{a}}$ Jordi Peña-Casanovaa, d \\ Teodoro del Ser ${ }^{\mathrm{a}, \mathrm{b}}$ Bob Woods ${ }^{\mathrm{e}}$ Cornelia Beck ${ }^{j}$ Stefanie Auer ${ }^{\mathrm{m}}$ Claudia Lai $^{\mathrm{n}}$ Aimee Spector $^{\mathrm{f}}$ \\ Sam Faziok $^{k}$ John Bond ${ }^{g}$ Miia Kivipelto ${ }^{\circ}$ Henry Brodaty $^{p}$ José Manuel Rojo ${ }^{c}$ Helen Collins $^{\mathrm{h}}$ \\ Linda Teri ${ }^{l}$ Mary Mittelman ${ }^{i}$ Martin Orrell ${ }^{f}$ Howard H. Feldman $^{q}{ }^{r} \quad$ Ruben Muñiz ${ }^{a}$

\begin{abstract}
${ }^{a}$ Maria Wolff Foundation, ${ }^{b}$ Noscira and 'Superior Council of Scientific Research, Madrid, and d Hospital del Mar and

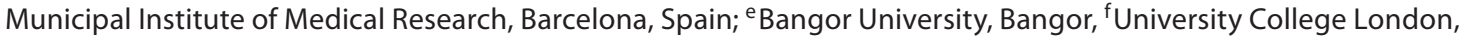
London, 9 Newcastle University, Newcastle, and h Cochrane Dementia and Cognitive Improvement Group, Oxford, UK; ' $N$ ew York University Medical Center, New York, N.Y., jUniversity of Arkansas for Medical Sciences, Little Rock, Ark., kAlzheimer's Association, Chicago, Ill., and 'University of Washington School of Nursing, Seattle, Wash., USA; mMAS Alzheimerhelp, Bad Ischl, Austria; ${ }^{n}$ Hong Kong Polytechnic University, Hong Kong,

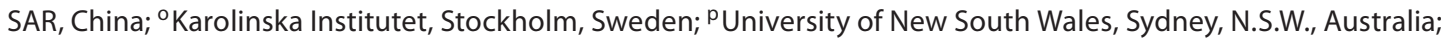
"Division of Neurology, University of British Columbia, Vancouver, B.C., Canada, and ' Neuroscience, Bristol Myers Squibb, Wallingford, Conn., USA
\end{abstract}

\section{Key Words}

Alzheimer's disease, nonpharmacological therapy • Efficacy evaluation

\begin{abstract}
Introduction: Nonpharmacological therapies (NPTs) can improve the quality of life (QoL) of people with Alzheimer's disease (AD) and their carers. The objective of this study was to evaluate the best evidence on the effects of NPTs in AD and related disorders (ADRD) by performing a systematic review and meta-analysis of the entire field. Methods: Existing reviews and major electronic databases were searched for randomized controlled trials (RCTs). The deadline for study inclusion was September 15, 2008. Intervention categories and outcome domains were predefined by consensus. Two researchers working together detected 1,313 candidate studies of which 179 RCTs belonging to 26 intervention categories were selected. Cognitive deterioration had to be documented in all participants, and degenerative etiology
\end{abstract}

(indicating dementia) had to be present or presumed in at least $80 \%$ of the subjects. Evidence tables, meta-analysis and summaries of results were elaborated by the first author and reviewed by author subgroups. Methods for rating level of evidence and grading practice recommendations were adapted from the Oxford Center for Evidence-Based Medicine. Results: Grade A treatment recommendation was achieved for institutionalization delay (multicomponent interventions for the caregiver, CG). Grade B recommendation was reached for the person with dementia (PWD) for: improvement in cognition (cognitive training, cognitive stimulation, multicomponent interventions for the PWD); activities of daily living (ADL) (ADL training, multicomponent interventions for the PWD); behavior (cognitive stimulation,

Steering Committee: J.O., B.R., L.C. and R.M.; Project Workgroup: J.O., B.R., L.C., I.C., J.P.-C., T. del S., B.W., C.B., S.A., C.L., A.S., S.F., J.B., M.K., H.B., J.M.R., H.C., L.T., M.M., M.O., H.H.F. and R.M.; principal author: J.O.

\section{KARGER \\ Fax +41613061234 E-Mail karger@karger.ch} www.karger.com

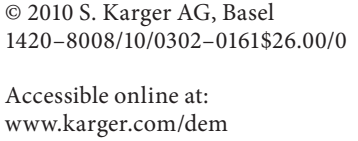

Ruben Muñiz

Maria Wolff Foundation

Río Sil 15

ES-28669 Boadilla del Monte, Madrid (Spain)

Tel. +34 609170 712, Fax +34 916320 363, E-Mail ruben@mariawolff.es 
multicomponent interventions for the PWD, behavioral interventions, professional CG training); mood (multicomponent interventions for the PWD); QoL (multicomponent interventions for PWD and CG) and restraint prevention (professional CG training); for the $C G$, grade $B$ was also reached for: CG mood (CG education, CG support, multicomponent interventions for the CG); CG psychological well-being (cognitive stimulation, multicomponent interventions for the CG); CG QoL (multicomponent interventions for PWD and CG). Conclusion: NPTs emerge as a useful, versatile and potentially cost-effective approach to improve outcomes and QoL in ADRD for both the PWD and CG.

Copyright $\odot 2010$ S. Karger AG, Base

\section{Introduction}

Alzheimer's disease (AD), which is frequently preceded by a prodromal mild cognitive impairment (MCI) stage, is a long process with a potential duration of 20 years or even longer, for people who survive into the final substages of the disease process [1]. For all stages of dementia, particularly for the most severely impaired individuals with immobility, inability to speak and other disabilities, it is vital that the basic human needs for wellbeing, movement, dignity, social interaction and fundamental human rights are protected [2]. It is important to ensure that basic and higher human needs are met and to be aware of the continued capacity to learn, to think, to feel, to seek to influence their environment, experience the sense of being loved and cared for, and the potential for happiness and equanimity of the person with dementia (PWD) [3].

The pathological process in $\mathrm{AD}$, affecting cognition, functioning and behavior, and the continuing human needs accompanying the evolution of $\mathrm{AD}$ provide a wealth of opportunities for environmental, social and therapeutic intervention. Although pharmacotherapies appear to slow aspects of AD symptom progression, the current limits on the effectiveness of drugs and the requirement for a range of options highlight the need for robust evaluations of nonpharmacological therapeutic intervention in $\mathrm{AD}$. Considering the millions of people worldwide with $\mathrm{AD}$ [4] and corresponding societal costs in terms of management and care [5], there is a significant lack of funding for the systematic research of nonpharmacological therapy (NPT). Moreover, the need for NPT research in $\mathrm{AD}$ is made more acute because of the suffering that results from the widespread suboptimal care due to the absence of the essential evidence required to show what is useful and cost-effective. Despite this there has been an exponential increase in the research literature on NPTs in AD. This paper presents the results of a worldwide research collaboration to review the evidence for the effectiveness of NPTs in AD and related disorders (ADRD). We hope that this review will provide a platform for continuing advances as well as a rationale for immediate improvements in therapeutic interventions, to improve services and care for persons with ADRD.

\section{Methods}

A core Steering Committee subgroup of 4 NPT Project Workgroup members formulated the methodology of the review, coordinated the efforts of other involved investigators and wrote the manuscript. A nonpharmacological intervention was defined as 'any theoretically based, nonchemical, focused and replicable intervention, conducted with the patient or the caregiver (CG), which potentially provided some relevant benefit'.

Candidate studies were first identified by existing reviews, which were obtained from electronic databases and via the input of NPT Project members (online supplementary material, www. karger.com/doi/10.1159/000316119). In a second step, additional candidate studies were identified by searches of the following electronic databases: Medline, PsycINFO, CINAHL, Embase, Lilacs and the Cochrane Dementia and Cognitive Improvement Group Specialized Register. The deadline for study inclusion was a publication date of September 15, 2008.

For a candidate study to be selected, 5 inclusion criteria had to be fulfilled:

(1) parallel-group randomized controlled trial (RCT);

(2) publication in a peer-reviewed journal;

(3) all participants had cognitive impairment or dementia, at least $80 \%$ due to ADRD; degenerative and mixed dementias were included under the ADRD rubric, but pure vascular dementia and other dementias secondary to non-degenerative, identified conditions, were not included. For MCI and other descriptions of cognitive impairment, an underlying ADRD etiology was assumed unless otherwise specified;

(4) the efficacy of a nonpharmacological intervention was tested in at least 1 of the following domains: (a) for the patient cognition, activities of daily living (ADLs), behavior, mood, combined scales, physical domain, quality of life (QoL), institutionalization, restraint usage (either physical or chemical restraint) or mortality; (b) for the CG (professional or nonprofessional) - mood, psychological well-being (PWB), objective burden or QoL; (c) cost-effectiveness;

(5) appropriate statistical analyses were required; both withinand between-group comparisons were acceptable; an RCT was classified as 'positive' if statistically significant differences between experimental and control groups were reported $(\mathrm{p}<$ 0.05); post-hoc within-group comparisons were accepted without adjustments for multiple comparisons.

All assessments were considered valid for interpretation of results, including follow-up assessments once the intervention program had ended. Usual care was accepted as an adequate control condition. 
Fig. 1. Literature search and study selection process. $\mathrm{PRJ}=$ Peer-reviewed journal; $\mathrm{RCT}=$ randomized controlled trial.

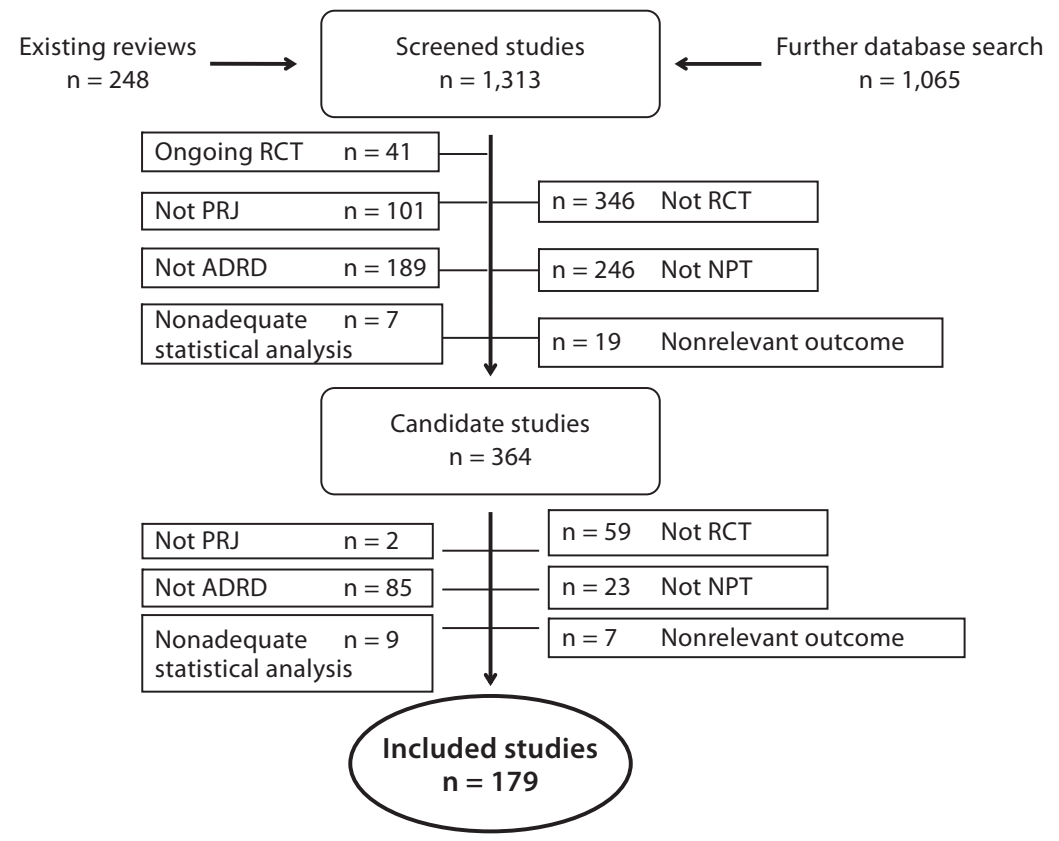

Before initiating the search, the Project Workgroup delineated a set of intervention categories (e.g. cognitive stimulation, music therapy etc.) and key words (fig. 1). Categories and key words were modified and combined when these procedures were considered useful in the search process. In a first step, reviews and paper abstracts were used to discard studies that clearly did not fulfill at least 1 of the 5 inclusion criteria. In all other cases, the complete paper was consulted for decisions regarding inclusion (online supplementary material, www.karger.com/doi/10.1159/000316119). The process of collecting information with respect to study inclusion in this analysis was performed collectively by 2 Workgroup members (J.O. and I.C.). Doubts and discrepancies were resolved by discussion.

An evidence table was developed for each intervention category by the principal author (J.O.). These tables contained sample characteristics, descriptions of interventions, outcomes in the different domains and time periods, data quality descriptors and reference citations of all the included RCTs which fulfilled the study criteria. Where adequate data were available, meta-analysis was performed. When several measures belonging to a single domain were utilized in the same RCT, the measure that was mentioned first in the study method section was selected for the meta-analysis. If necessary data from an included study were not available from the published papers, the study authors were contacted in an effort to include applicable information. Overall effect sizes and odds ratios were calculated using a fixed-effects model. For continuous variables, effect sizes were defined as posttreatment change in the experimental condition minus posttreatment change in the control condition, divided by the pooled standard deviation [6]. For the analysis of institutionalization and death, odds ratios were calculated using Peto's log rank test [7]. Software Stata V10, SSC METAN (Bradburn M.J., Deeks J.J., Altman D.G., University of Bristol, UK) was used for analyses (www.stata.com).

An evidence table and corresponding materials for each intervention category were sent to 2 NPT Project Workgroup members for review. Workgroup members were not permitted to review their own studies or any studies within the same intervention category as their published work. Recommendations for practice were established by consensus between the principal author (J.O.) and the 2 Workgroup members reviewing the intervention category after appraising both individual studies within the category and meta-analysis results. Oxford Center of Evidence-Based Medicine guidelines were followed (www.cebm.net). The Oxford guideline grading of practice recommendations scores a grade $\mathrm{A}$ recommendation for consistent high-quality RCTs and a grade $\mathrm{B}$ recommendation for consistent low-quality RCTs. A high-quality RCT was defined for this systematic review if it fulfilled all of the following criteria:

(1) cognitive impairment of degenerative or mixed (i.e. degenerative + secondary) etiology was documented in all participant subjects;

(2) study groups had comparable (or statistically controlled) characteristics at baseline;

(3) a detailed description of intervention was given;

(4) effects were measured by independent and blind evaluators (nonblind assessments were accepted for institutionalization and death);

(5) validated outcome measures were used; 
Table 1. Results in the intervention categories by outcome domains

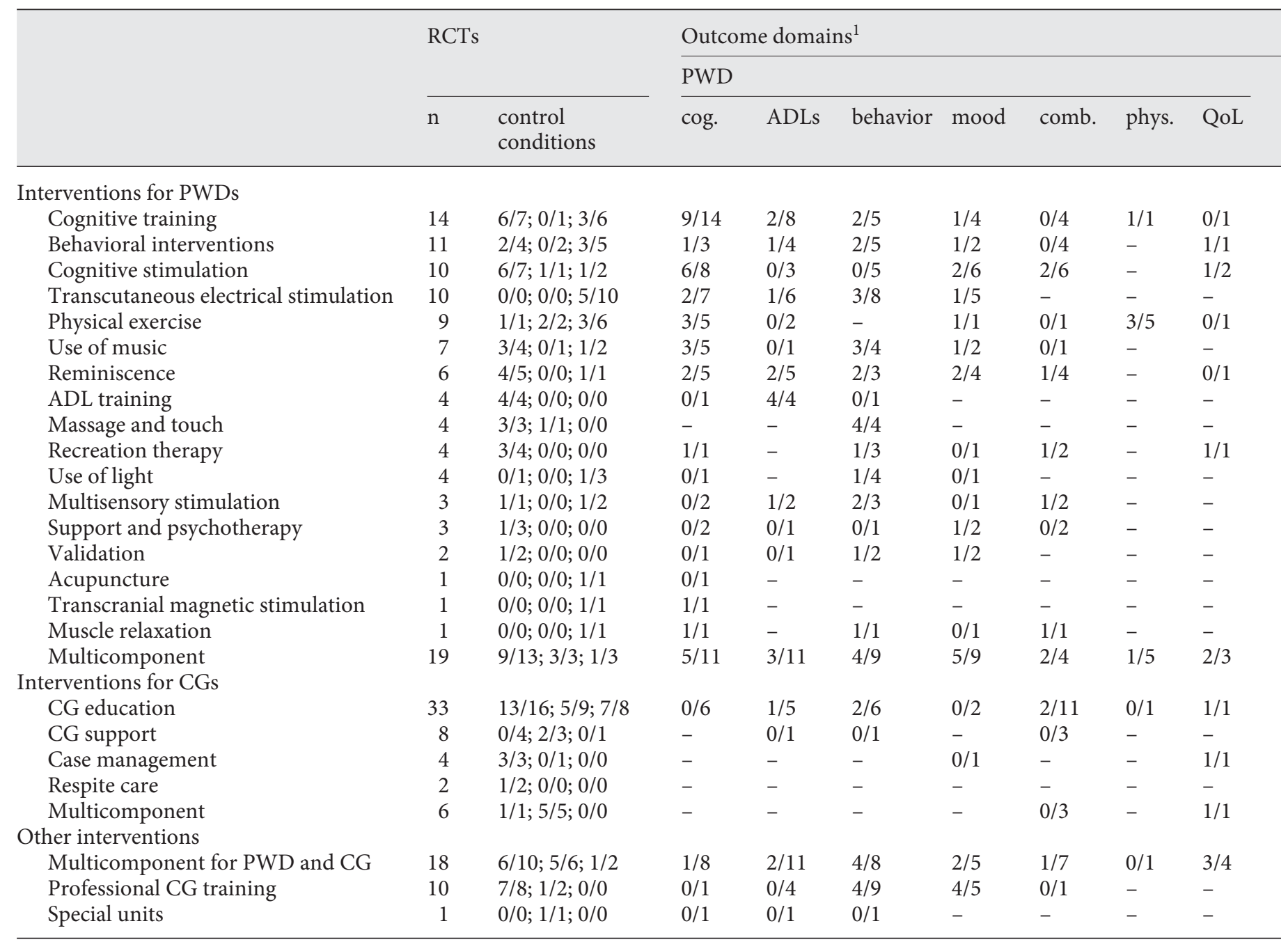

$\mathrm{n}=$ Number of RCTs for each intervention category (some RCTs tested interventions from more than one category); control conditions: first ratio $=$ number of positive RCTs among those including a usual-care control group; second ratio = number of positive RCTs among those including some (usually minimal) social attention control group but not a usual-care control group; third ratio = number of positive RCTs among those that only included a control group offering a similar level of social attention compared to the experimental group. Cog. = Cognition; comb. $=$ scales combining cognition, ADLs, behavior and mood; phys. = physical domain; PWB = psychological well-being; obj. = objective; inst. $=$ institutionalization.
(6) intention-to-treat principles were applied; observed cases, last-observation-carried-forward- and regression-based analyses were accepted); exclusions from analyses on the basis of intervention compliance were not permitted;

(7) effect was assessed in at least 30 patients and $80 \%$ of randomized patients per study group, and all losses were explained.

Interventions were considered for recommendation when data from at least 2 studies that tested the effect of a set of similar interventions, in the same outcome domain, were available. To establish practice recommendation, positive results (i.e. $95 \%$ confidence interval of global effect size not including zero), homogeneous results ( $\mathrm{p}$ for Cochran $\mathrm{Q}<0.05$ ) and clinical relevance had to be present.
In the textual descriptions, the following definitions were used: MCI, mild dementia, moderate dementia, moderately severe dementia and severe dementia, which were equivalent to Global Deterioration Scale [8] stages 3, 4, 5, 6 and 7, respectively. When the Global Deterioration Scale severity was not specified in the publication, it was estimated in accordance with collateral clinical data. In the assessment of potential recommendations, RCTs conducted exclusively on MCI were analyzed separately. Once the results and discussion sections had been compiled, a complete draft of the manuscript was sent to all NPT Project Workgroup members for final comments and approval. 


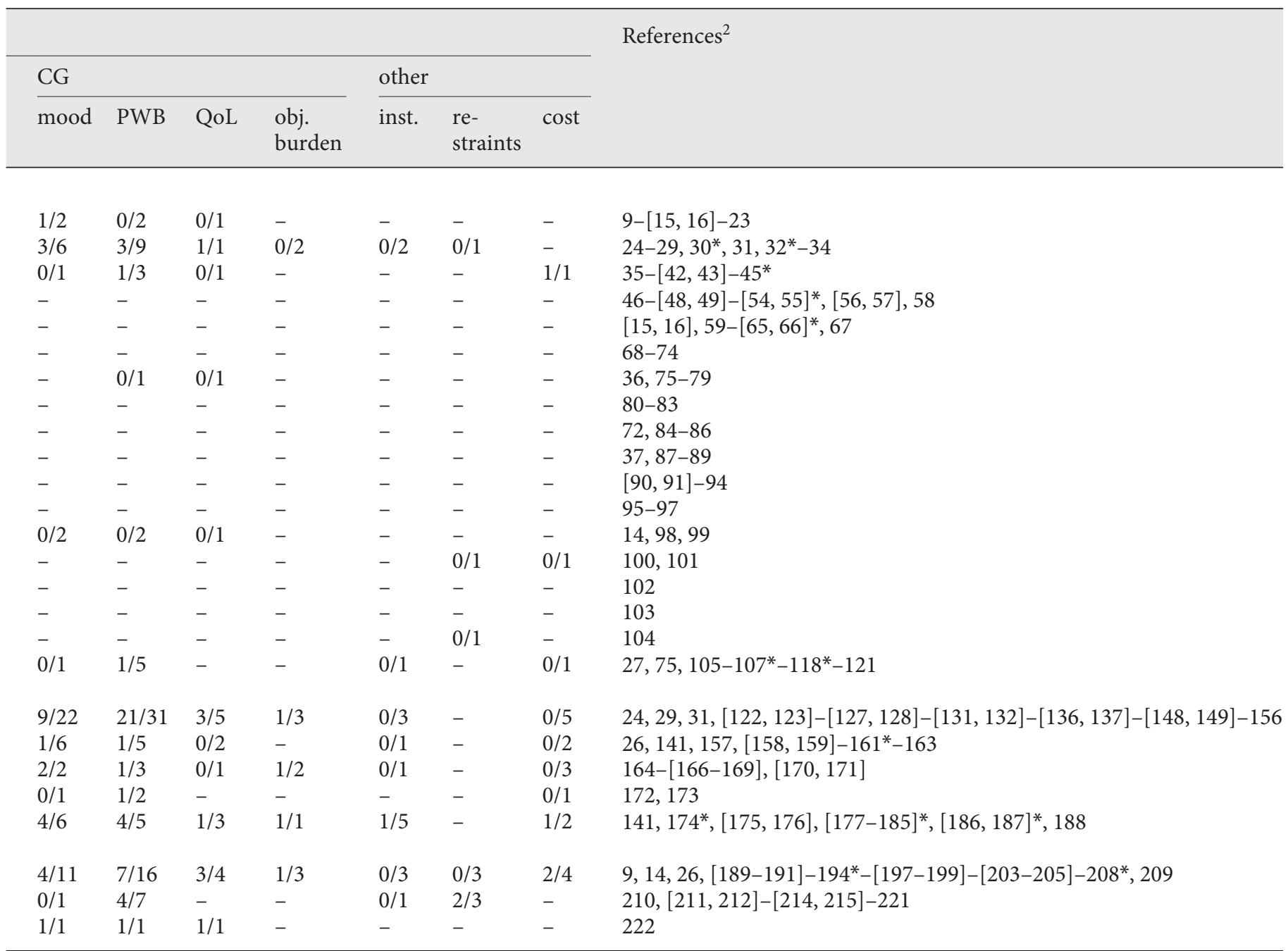

${ }^{1}$ Figures represent number of positive RCTs per total number of RCTs that tested the corresponding outcome domain; mood items were sometimes included in behavior (PWD) or PWB (CG) scales; - = no RCTs were identified.

${ }^{2}$ References from the same RCT are in square brackets; highquality RCTs are marked with an asterisk.

\section{Results}

A comprehensive summary of intervention categories, results and the included publications [9-222] is shown in table 1. Most publications (97\%) were in English. The number of randomized participants ranged from 8 [68] to 7,949 [166], and intervention duration varied from a few minutes (i.e. short single sessions) $[51,52,152]$ to 11 years [184]. A chronological perspective shows an exponential increase in the number of RCTs (fig. 2). The pro- portion of positive RCTs among all RCTs conducted remained stable over time. Only 13 high-quality trials were found $[30,32,45,54,65,107,118,161,174,177,186,194$, 208] of which 7 (54\%) were positive; 113 of 166 (68\%) lowquality trials were positive ( $\mathrm{p}=0.360$, Fisher's exact test).

Many categories had only 1 RCT (e.g. acupuncture), and these are shown in table 1, but are no longer mentioned in this paper. Due to intervention heterogeneity, some categories were segmented or narrowed for analysis of results. The resulting subcategories were as fol- 


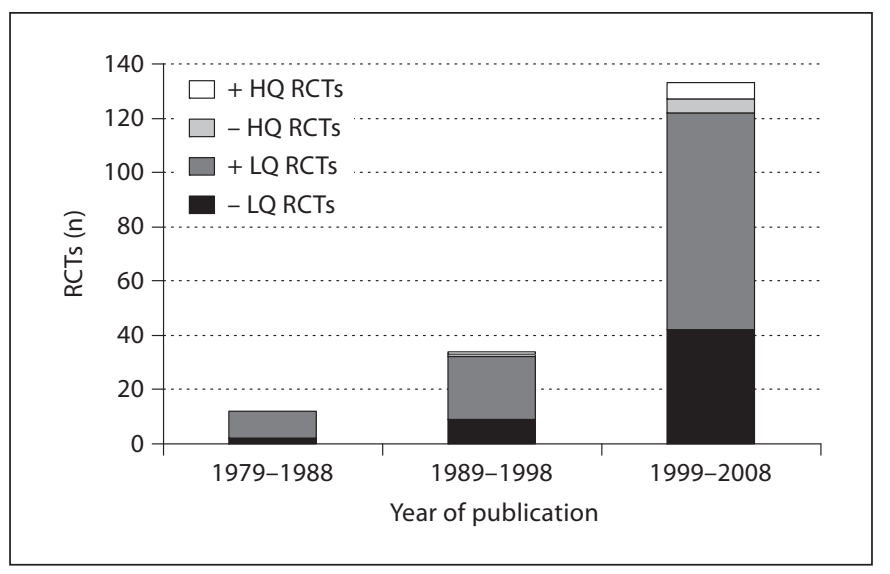

Fig. 2. RCTs included in this review by quality and results. $L Q=$ Low quality; $\mathrm{HQ}=$ high quality; + = RCT showing a positive result $(\mathrm{p}<0.05)$ in at least 1 domain; $-=$ RCT showing neutral results.

lows: cognitive training (individual, group or computerbased sessions); cognitive stimulation (group or individual sessions); reminiscence (group or individual sessions); use of music (recorded music); transcutaneous electrical stimulation (cranial or dorsal stimulation); use of light (morning bright light); massage and touch (therapeutic touch); physical exercise (walking or comprehensive exercise); multicomponent interventions for the PWD (enriched group cognitive stimulation, enriched group cognitive training or physical exercise and music); CG support (electronic devices); CG education (coping skills individual sessions, coping skills group sessions for community-dwelling PWD or coping skills group sessions for institutionalized PWD); multicomponent interventions for PWD and CG (in-home counseling or support groups); professional CG interventions (education on dementia management or alternatives to restraint).

Given the paucity of high-quality data, potential grade A recommendations could only be addressed for the effect of multicomponent interventions for the CG on institutionalization and death. Considering high- and lowquality evidence together, limited or inconclusive results were found in the following domains: combined domain, physical domain, objective burden, cost and death. For the remaining domains, recommendations could be established at grade B level.

\section{NPTs to Delay Institutionalization}

The pooling of 3 high-quality RCTs testing multicomponent interventions for the CG demonstrated a delay in the institutionalization of mild to moderately severe $\mathrm{AD}$ persons when compared to usual care $[174,177,186]$. The essential components of these interventions were individual assessment, information, counseling and support. Sessions lasted from 30 to $90 \mathrm{~min}$ and were conducted with a frequency of every 2 months to twice monthly by social workers [174], nurses [177] or trained personnel [186]. Skill training [177, 186], respite services [174], support groups $[177,186]$ and continuous availability of a therapist $[174,177]$ were particularly stressed. After 6 or 12 months of intervention, the overall institutionalization rate was $10.6 \%$ in the intervention groups versus $14.9 \%$ in the control groups (risk reduction $0.67,95 \%$ confidence interval 0.49-0.92; fig. 3). In one of these RCTs, after more than 11 years of intervention, the delay in nursing home placement reached 557 days [183] (grade A recommendation).

\section{NPTs to Improve Cognition}

The training of specific cognitive abilities in small groups (cognitive training, group sessions) produced an improvement specific to those cognitive skills. Two small RCTs demonstrated improvement of verbal and visual learning after teaching of memory strategies had been conducted daily [11] or twice weekly [9]. Another small RCT, conducting weekly sessions, was neutral [18] but meta-analysis yielded homogenous and positive results (table 2). Positive effects on cognition were also demonstrated when cognitive training in individual sessions was conducted. In 2 RCTs, this intervention was administered by the family CG $[13,14]$.

For cognitive stimulation group sessions, there were trials indicating significant improvements in measures of attention, memory [35, 40], orientation, language [37] and general cognition $[38,42]$. The augmentation of cognitive stimulation with other components (e.g. relaxation) produced benefits in general cognition (multicomponent interventions for the PWD, enriched group cognitive stimulation; table 2).

In a high-quality RCT, cognitive stimulation was delivered by CGs in patients' homes as an adjunct to donepezil. A benefit of 2.9 points over medication alone was shown on the cognitive subscale of the Alzheimer's Disease Assessment Scale [223] for those receiving the combined treatments $(\mathrm{p}=0.01)$ [45].

\section{NPTs to Improve ADLs}

$\mathrm{ADL}$ training was used to ameliorate the performance of ADL decrements in cognitively impaired nursing home residents. Positive results compared to a usual-care 


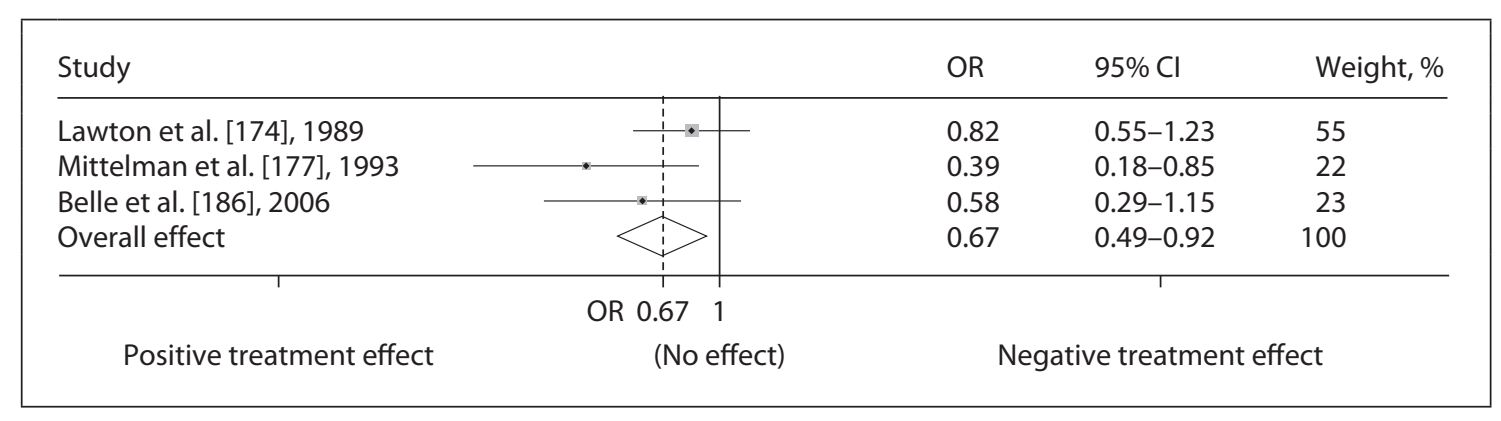

Fig. 3. Multicomponent interventions for the CG and institutionalization delay: meta-analysis of high-quality RCTs. The odds ratio (OR) of 0.67 indicates 33\% less institutionalization after 6-12 months of multicomponent intervention compared to the minimal support or usual-care control group $(\mathrm{Q}=2.95, \mathrm{p}=0.228)$. CI $=\mathrm{Confi-}$ dence interval; $\mathrm{Q}=$ test for heterogeneity of effects ( $\mathrm{p}>0.05$ indicates homogeneity).

control group were reported in all the identified studies. The interventions included: scheduling and prompting used to reduce urinary incontinence [80]; graded assistance to improve individual autonomy [81]; prompting and reinforcement during meals to improve eating independence [82], and a specific way-finding intervention to assist residents in locating a dining room [83].

Group sessions of cognitive stimulation, reminiscence and relaxation (multicomponent interventions for PWD, enriched group cognitive stimulation) improved orientation after 3 months whereas persons receiving usual care deteriorated [110]. Within this subcategory, a trend of less deterioration in instrumental ADLs was observed after 1 year of cognitive stimulation plus psychomotor exercises, using minimal support as a control group [109]. Another RCT conducting less frequent sessions was neutral [108]; however, meta-analysis of the subcategory indicated positive results (table 2).

\section{NPTs to Improve Behavior}

The highest effect on behavior was attained by pooling 3 individually neutral small RCTs of cognitive stimulation group sessions that were performed in behaviorally disturbed PWDs who lived in institutions. The measures utilized included problem behavior [36], control of emotions [37] and disruptive behavior [39]. A moderate improvement in general behavior [108] and withdrawal [110] was also attained in less behaviorally disturbed community-dwelling PWDs after conducting multicomponent interventions in the PWD (enriched group cognitive stimulation).

Interventions specifically targeted at behavior (i.e. behavioral interventions) performed by individual work with the family CG reduced behavior disturbance in
PWDs displaying agitation [27, 32], aggressive behavior [28], depression [32] or problem behaviors [29]. One of these RCTs compared behavioral management, haloperidol, trazodone and placebo pills. A similar improvement was observed in the 4 groups, but behavioral management produced fewer adverse events than the 2 medications [27]. In a high-quality RCT, behavior management was not superior to usual care in 2 traditional measures of behavior disturbance; however, a reduction in the frequency and severity of problematic behaviors identified at baseline by CGs of the experimental group was reported by 57 and $52 \%$ of CGs, respectively [32].

Four RCTs tested the effect of professional CG training as dementia management on the behavior of institutionalized PWDs. Agitation was reduced after treatment in 2 individual RCTs [210,217] and meta-analysis yielded a mild positive effect.

\section{NPTs to Improve Mood}

Multicomponent interventions for PWD (enriched group cognitive stimulation) produced a progressive improvement of affective symptoms that reached statistical significance after 1 year of treatment. Although not reported, baseline prevalence of clinical depression in these RCTs seemed to be low $[108,109]$. Another RCT conducting a 10 -week intervention produced a neutral result [110]. The pooled results of the 3 RCTs were positive (table 2).

In a high-quality trial, a 6-month individualized program of physical exercise plus behavioral management was implemented. CGs ( $80 \%$ spouses) were encouraged to identify pleasant activities and to promote positive interactions. Benefits in mood were observed that reached statistical significance after the 3-month period of inten- 
Table 2. NPTs recommended in ADRD on the basis of homogeneous evidence from low-quality RCTs (grade B recommendations)

\begin{tabular}{|c|c|c|c|c|c|}
\hline Outcome & NPT essential characteristics & $\begin{array}{l}\text { Session format and } \\
\text { intervention duration }\end{array}$ & $\begin{array}{l}\text { PWD characteristics } \\
\text { and setting }\end{array}$ & $\begin{array}{l}\text { Effect size and } \\
\text { homogeneity }^{1}\end{array}$ & Ref. $^{2}$ \\
\hline \multirow[t]{4}{*}{ Cognition } & $\begin{array}{l}\text { Cognitive training, group sessions: the teaching of } \\
\text { strategies (e.g. mental imagery) to improve verbal } \\
\text { learning and other cognitive functions }\end{array}$ & $\begin{array}{l}45-90 \mathrm{~min} \\
2-7 / \text { week, } \\
11-25 \text { days }\end{array}$ & $\begin{array}{l}\text { GDS 3-4, } \\
\text { community }\end{array}$ & $\begin{array}{l}0.594(0.052-1.137) \\
\mathrm{k}=3, \mathrm{n}=67 \\
\mathrm{Q}=2.34, \mathrm{p}=0.310\end{array}$ & $9,11,18$ \\
\hline & $\begin{array}{l}\text { Cognitive stimulation, group sessions: themed } \\
\text { activities to orientate and actively stimulate } \\
\text { cognition through, e.g., association and } \\
\text { categorization }\end{array}$ & $\begin{array}{l}30-60 \mathrm{~min} \\
2-5 / \text { week, } \\
4-24 \text { weeks }\end{array}$ & $\begin{array}{l}\text { GDS } 4-6 \text {, } \\
\text { community (day } \\
\text { center), nursing } \\
\text { home, residential } \\
\text { home, long-term } \\
\text { care hospital }\end{array}$ & $\begin{array}{l}0.442(0.197-0.688) \\
\mathrm{k}=6, \mathrm{n}=270 \\
\mathrm{Q}=4.09, \mathrm{p}=0.537\end{array}$ & $\begin{array}{l}35-37,38^{3} \\
40-42\end{array}$ \\
\hline & $\begin{array}{l}\text { Cognitive training, individual sessions: } \\
\text { the teaching of strategies (e.g. spaced retrieval, } \\
\text { dual cognitive support) to improve verbal } \\
\text { learning and other cognitive functions }\end{array}$ & $\begin{array}{l}20-60 \mathrm{~min} \\
2-6 / \text { week, } \\
6-26 \text { weeks }\end{array}$ & $\begin{array}{l}\text { GDS 3-5, } \\
\text { community, } \\
\text { nursing home }\end{array}$ & $\begin{array}{l}0.403(0.085-0.721) \\
\mathrm{k}=7, \mathrm{n}=255 \\
\mathrm{Q}=9.45, \mathrm{p}=0.150\end{array}$ & $\begin{array}{l}10,13,14,16 \\
17,19,20\end{array}$ \\
\hline & $\begin{array}{l}\text { Multicomponent interventions for PWD, enriched } \\
\text { group cognitive stimulation: cognitive stimulation } \\
\text { and some of the following: reminiscence, physical } \\
\text { exercise, ADL training, support }\end{array}$ & $\begin{array}{l}90-210 \mathrm{~min} \\
1-2 / \text { week, } \\
6-52 \text { weeks }\end{array}$ & $\begin{array}{l}\text { GDS } 3-5 \text {, } \\
\text { community, } \\
\text { nursing home }\end{array}$ & $\begin{array}{l}0.307(0.036-0.578) \\
\mathrm{k}=5, \mathrm{n}=213 \\
\mathrm{Q}=1.60, \mathrm{p}=0.808\end{array}$ & $\begin{array}{l}108-110,114, \\
120\end{array}$ \\
\hline \multirow[t]{2}{*}{ ADLs } & $\begin{array}{l}\text { ADL training: guided performance providing the } \\
\text { minimal required assistance to complete target } \\
\text { ADLs, e.g. verbal prompting and reinforcement to } \\
\text { avoid incontinence }\end{array}$ & $\begin{array}{l}\text { Intervention integrated } \\
\text { in usual care, or individual } \\
\text { ( } 30 \mathrm{~min} \text {, } \\
3 / \text { week) or group } \\
\text { ( } 2.5 \mathrm{~h}, 5 / \text { week) sessions, } \\
3 \text { days to } 20 \text { weeks }\end{array}$ & $\begin{array}{l}\text { GDS 3-6, } \\
\text { nursing home }\end{array}$ & $\begin{array}{l}0.412(0.003-0.821) \\
\mathrm{k}=3, \mathrm{n}=95 \\
\mathrm{Q}=1.33, \mathrm{p}=0.514\end{array}$ & $80^{3}, 81-83$ \\
\hline & $\begin{array}{l}\text { Multicomponent interventions for the PWD, } \\
\text { enriched group cognitive stimulation: cognitive } \\
\text { stimulation and some of the following: } \\
\text { reminiscence, physical exercise, ADL training, } \\
\text { support }\end{array}$ & $\begin{array}{l}90-210 \mathrm{~min}, \\
1-2 / \text { week, } \\
10-52 \text { weeks }\end{array}$ & $\begin{array}{l}\text { GDS 3-5, } \\
\text { community }\end{array}$ & $\begin{array}{l}0.369(0.062-0.676) \\
\mathrm{k}=3, \mathrm{n}=167 \\
\mathrm{Q}=1.25, \mathrm{p}=0.535\end{array}$ & $108-110$ \\
\hline \multirow[t]{4}{*}{ Behavior } & $\begin{array}{l}\text { Cognitive stimulation, group sessions: themed } \\
\text { activities to orientate and actively stimulate } \\
\text { cognition through, e.g. association and } \\
\text { categorization }\end{array}$ & $\begin{array}{l}30-60 \mathrm{~min}, \\
3-5 / \text { week, } \\
4-11 \text { weeks }\end{array}$ & $\begin{array}{l}\text { GDS 5-6, } \\
\text { behavior } \\
\text { disturbance, } \\
\text { nursing home, long- } \\
\text { term care hospital }\end{array}$ & $\begin{array}{l}0.608(0.092-1.124) \\
\mathrm{k}=3, \mathrm{n}=62 \\
\mathrm{Q}=1.03, \mathrm{p}=0.598\end{array}$ & $36,37,39$ \\
\hline & $\begin{array}{l}\text { Multicomponent interventions for the PWD, } \\
\text { enriched group cognitive stimulation: } \\
\text { cognitive stimulation, reminiscence and } \\
\text { some of the following: relaxation, support }\end{array}$ & $\begin{array}{l}90 \mathrm{~min}, \\
1-2 / \text { week, } \\
10-52 \text { weeks }\end{array}$ & $\begin{array}{l}\text { GDS 3-5, } \\
\text { community }\end{array}$ & $\begin{array}{l}0.604(0.181-1.027) \\
\mathrm{k}=2, \mathrm{n}=90 \\
\mathrm{Q}=0.00, \mathrm{p}=0.952\end{array}$ & 108,110 \\
\hline & $\begin{array}{l}\text { Behavioral interventions: analysis and } \\
\text { modification of antecedents and consequences of } \\
\text { behavior, e.g. use of distraction techniques } \\
\text { to mitigate aggressive episodes }\end{array}$ & $\begin{array}{l}\text { Individual or group sessions } \\
\text { with } \\
\text { family CG, } \\
60-90 \mathrm{~min} \text {, } \\
1 \text { /week to } 1 / \text { month, } \\
1-26 \text { weeks }\end{array}$ & $\begin{array}{l}\text { GDS } 4-6 \text {, } \\
\text { behavior } \\
\text { disturbance, } \\
\text { community }\end{array}$ & $\begin{array}{l}0.565(0.209-0.921) \\
\mathrm{k}=3, \mathrm{n}=167 \\
\mathrm{Q}=2.48, \mathrm{p}=0.290\end{array}$ & $\begin{array}{l}27^{3}-29,32^{* 3} \\
33\end{array}$ \\
\hline & $\begin{array}{l}\text { Professional CG training, dementia management: } \\
\text { education and training of nursing assistants and } \\
\text { other direct care staff in knowledge of dementia, } \\
\text { acknowledgement of resident's experiences, } \\
\text { communication techniques and behavior } \\
\text { management }\end{array}$ & $\begin{array}{l}\text { Group workshops followed } \\
\text { by individual sessions, } \\
30 \text { min to half day, } \\
3 / \text { month, } \\
8 \text { weeks to } 3 \text { months }\end{array}$ & $\begin{array}{l}\text { GDS } 4-7, \text { mood or } \\
\text { behavior } \\
\text { disturbance, } \\
\text { nursing home, } \\
\text { assisted living } \\
\text { residence }\end{array}$ & $\begin{array}{l}0.223(0.017-0.428) \\
\mathrm{k}=4, \mathrm{n}=370 \\
\mathrm{Q}=2.08, \mathrm{p}=0.557\end{array}$ & $\begin{array}{l}210,212,214, \\
217\end{array}$ \\
\hline Mood & $\begin{array}{l}\text { Multicomponent interventions for the PWD, } \\
\text { enriched group cognitive stimulation: cognitive } \\
\text { stimulation and some of the following: } \\
\text { reminiscence, physical exercise, ADL training, } \\
\text { support }\end{array}$ & $\begin{array}{l}90-210 \mathrm{~min}, \\
1-2 / \text { week, } \\
10-52 \text { weeks }\end{array}$ & $\begin{array}{l}\text { GDS 3-5, } \\
\text { community }\end{array}$ & $\begin{array}{l}0.376(0.066-0.686) \\
\mathrm{k}=3, \mathrm{n}=164 \\
\mathrm{Q}=1.75, \mathrm{p}=0.417\end{array}$ & $108-110$ \\
\hline
\end{tabular}


Table 2 (continued)

\begin{tabular}{|c|c|c|c|c|c|}
\hline Outcome & NPT essential characteristics & $\begin{array}{l}\text { Session format and } \\
\text { intervention duration }\end{array}$ & $\begin{array}{l}\text { PWD characteristics } \\
\text { and setting }\end{array}$ & $\begin{array}{l}\text { Effect size and } \\
\text { homogeneity }\end{array}$ & Ref. $^{2}$ \\
\hline QoL & $\begin{array}{l}\text { Multicomponent interventions for PWD and CG, } \\
\text { in-home counseling: individualized programs for } \\
\text { effective dementia care based on comprehensive } \\
\text { assessment, environment modifications and } \\
\text { continuous counseling and support }\end{array}$ & $\begin{array}{l}\text { Individual sessions with } \\
\text { family CG, } \\
60-90 \text { min, } \\
\text { 1-2/week, } \\
6 \text { weeks to } 4 \text { months }\end{array}$ & $\begin{array}{l}\text { GDS 4-5, } \\
\text { community }\end{array}$ & $\begin{array}{l}0.561(0.087-1.035) \\
\mathrm{k}=2, \mathrm{n}=170 \\
\mathrm{Q}=2.17, \mathrm{p}=0.141\end{array}$ & 204,209 \\
\hline \multirow[t]{4}{*}{ CG mood } & $\begin{array}{l}\text { CG education, coping skills, individual sessions: } \\
\text { intervention based on individual assessment, } \\
\text { information, problem solving, cognitive } \\
\text { restructuring and emotional support to mitigate } \\
\text { stress derived from caregiving }\end{array}$ & $\begin{array}{l}\text { Sessions usually at home, } \\
45-90 \text { min, sometimes } \\
\text { additional phone calls, } \\
1 \text { /week to } 1 / 3 \text { months, } \\
6 \text { weeks to } 24 \text { months }\end{array}$ & $\begin{array}{l}\text { GDS 4-6, } \\
\text { community }\end{array}$ & $\begin{array}{l}0.269(0.027-0.511) \\
\mathrm{k}=9^{4}, \mathrm{n}=431 \\
\mathrm{Q}=12.34, \mathrm{p}=0.137\end{array}$ & $\begin{array}{l}29,125^{3}, 134 \\
139-141 \\
146^{3}, 152,156\end{array}$ \\
\hline & $\begin{array}{l}\text { CG support, electronic devices: computer or } \\
\text { telephone systems providing information and } \\
\text { support }\end{array}$ & $\begin{array}{l}\text { Home installation of } \\
\text { electronic device for } \\
\text { use as needed or regular } \\
\text { support groups, } \\
6-12 \text { months }\end{array}$ & $\begin{array}{l}\text { GDS 4-6, } \\
\text { community }\end{array}$ & $\begin{array}{l}0.196(-0.004 \text { to } 0.395) \\
\mathrm{k}=5^{5}, \mathrm{n}=390 \\
\mathrm{Q}=0.64, \mathrm{p}=0.959\end{array}$ & $\begin{array}{l}141,158 \\
161^{*}, 162\end{array}$ \\
\hline & $\begin{array}{l}\text { CG education, coping skills, group sessions, com- } \\
\text { munity- } d \text { welling } P W D \text { : interventions based on in- } \\
\text { formation, problem solving and cognitive restruc- } \\
\text { turing to mitigate stress derived from caregiving }\end{array}$ & $\begin{array}{l}90-180 \text { min, } \\
1 / \text { week, } \\
4-16 \text { weeks }\end{array}$ & $\begin{array}{l}\text { GDS 4-6, } \\
\text { community }\end{array}$ & $\begin{array}{l}0.179(0.018-0.340) \\
\mathrm{k}=11^{6}, \mathrm{n}=636 \\
\mathrm{Q}=10.27, \mathrm{p}=0.417\end{array}$ & $\begin{array}{l}31,127,129 \\
131,135 \\
142-145,154\end{array}$ \\
\hline & $\begin{array}{l}\text { Multicomponent interventions for the CG: } \\
\text { long-term programs based on CG education and } \\
\text { support; other components (e.g. respite care, } \\
\text { support groups) are utilized according to } \\
\text { individual needs and possibilities }\end{array}$ & $\begin{array}{l}\text { Individual sessions with } \\
\text { family CG and (option) } \\
\text { other family members, } \\
60-90 \text { min, } 1 / 1-3 \text { weeks } \\
\text { (sessions may become less } \\
\text { frequent or substituted by } \\
\text { contacts as needed), } \\
6-12 \text { months }\end{array}$ & $\begin{array}{l}\text { GDS 4-6, } \\
\text { community }\end{array}$ & $\begin{array}{l}0.166(0.039-0.293) \\
\mathrm{k}=8^{7}, \mathrm{n}=1,102 \\
\mathrm{Q}=7.54, \mathrm{p}=0.375\end{array}$ & $\begin{array}{l}141,174^{3} \\
175,181,186 \\
188\end{array}$ \\
\hline \multirow[t]{2}{*}{ CG PWB } & $\begin{array}{l}\text { Cognitive stimulation, group sessions: themed } \\
\text { activities to orientate and actively stimulate } \\
\text { cognition through, e.g. association and } \\
\text { categorization }\end{array}$ & $\begin{array}{l}\text { 30-45 min, } \\
\text { 2-3/week, } \\
\text { 8-10 weeks }\end{array}$ & $\begin{array}{l}\text { GDS 4-6, } \\
\text { nursing home, } \\
\text { residential home, } \\
\text { day center }\end{array}$ & $\begin{array}{l}0.898(0.005-1.791) \\
\mathrm{k}=2, \mathrm{n}=67 \\
\mathrm{Q}=2.78, \mathrm{p}=0.095\end{array}$ & 39,41 \\
\hline & $\begin{array}{l}\text { Multicomponent interventions for the CG: } \\
\text { Long-term programs based on CG education and } \\
\text { support; other components (e.g. respite care, } \\
\text { support groups) are utilized according to } \\
\text { individual needs and possibilities }\end{array}$ & $\begin{array}{l}\text { Individual sessions with } \\
\text { family CG and (option) } \\
\text { other family members, } \\
90 \text { min, } 1 / 1-3 \text { weeks } \\
\text { (sessions may be substituted } \\
\text { by contacts as needed), } \\
6-8 \text { months }\end{array}$ & $\begin{array}{l}\text { GDS 4-6, } \\
\text { community }\end{array}$ & $\begin{array}{l}0.139(0.015-0.264) \\
\mathrm{k}=6^{8}, \mathrm{n}=991 \\
\mathrm{Q}=4.25, \mathrm{p}=0.514\end{array}$ & $\begin{array}{l}174^{3}, 175 \\
178,186,188\end{array}$ \\
\hline CG QoL & $\begin{array}{l}\text { Multicomponent interventions for PWD and CG, } \\
\text { in-home counseling: individualized programs for } \\
\text { effective dementia care based on comprehensive } \\
\text { assessment, environment modifications and } \\
\text { continuous CG counseling and support }\end{array}$ & $\begin{array}{l}\text { Home visits with family CG, } \\
60 \text { min, } 2 / \text { week to } \\
1 / 2 \text { weeks, } \\
5 \text { weeks to } 6 \text { months }\end{array}$ & $\begin{array}{l}\text { GDS 4-6, } \\
\text { community }\end{array}$ & $\begin{array}{l}0.678(0.357-0.998) \\
\mathrm{k}=2, \mathrm{n}=220 \\
\mathrm{Q}=1.36, \mathrm{p}=0.243\end{array}$ & $204,208^{*}$ \\
\hline Restraints & $\begin{array}{l}\text { Professional CG training, alternatives to restraint: } \\
\text { education of nursing staff on individualized care } \\
\text { to avoid physical restraint }\end{array}$ & $\begin{array}{l}\text { Group sessions, } \\
1-6 \mathrm{~h} \text {, } \\
1 / \text { week to } 1 / \text { month, } \\
7 \text { months }\end{array}$ & $\begin{array}{l}\text { GDS } 4-7 \text {, } \\
\text { nursing and } \\
\text { residential homes }\end{array}$ & $\begin{array}{l}-0.284(-0.529 \text { to }-0.039) \\
\mathrm{k}=2, \mathrm{n}=268 \\
\mathrm{Q}=0.28, \mathrm{p}=0.596\end{array}$ & 218,220 \\
\hline
\end{tabular}

GDS = Global Deterioration Scale [8]; PWB = psychological well-being.

${ }^{1}$ Overall effect size ( $95 \%$ confidence intervals in parentheses) was calculated, representing the difference between experimental and control groups at the end of intervention divided by the pooled standard deviation at baseline $(<0.2=$ no relevant effect, $0.2-0.5=$ mild effect, $0.5-0.8=$ moderate effect, $>0.8$ = intense effect); a fixed-effect model was applied; $\mathrm{k}=$ number of pooled RCTs; $\mathrm{n}$ = total number of analyzed individuals; homogeneity of effects among the individual studies was evaluated using the Cochran Q test ( $\mathrm{p}<$ 0.05 indicates heterogeneity of effects). ${ }^{2}$ High-quality RCTs are marked with an asterisk. ${ }^{3}$ Data from these RCTs were not available or could not be pooled for meta-analysis. ${ }^{4}$ Data of White and African American participants [139] and of White non-Hispanic and Cuban American participants [141] were considered individual studies. ${ }^{5}$ Data of White non-Hispanic and Cuban American participants [141] were considered individual studies. ${ }^{6}$ Data of Latino and Anglo participants [142] were considered individual studies. ${ }^{7}$ Data of White non-Hispanic and Cuban American participants [141] and of Hispanic, White and Black participants [186] were considered individual studies. ${ }^{8}$ Data of Hispanic, White and Black participants [186] were considered individual studies. 
sive treatment, but not after 3 months of additional maintenance treatment or up to 2-year follow-up assessments [107].

\section{NPTs to Improve QoL}

One intervention aimed at adapting home environment to PWD capacities and providing continuous counseling and support to the CG (multicomponent interventions for PWD and CG, in-home counseling) improved QoL as rated by the PWD [204]. Another intervention conducting less frequent sessions and measuring QoL as rated by the CG was neutral [209].

\section{NPTs to Improve CG Mood}

Four NPT categories demonstrated mild mood benefits in family CGs of community-dwelling PWDs. To deal with the stress derived from caregiving, CG education programs added problem-solving and cognitive restructuring techniques to the traditional information and support components of support groups. Particularly high responses were described in those CGs displaying high levels of depression [131] or anxiety [145] at baseline, and an association was described between the decrease in emotional involvement and improvement in mood after treatment [132]. Cognitive-behavioral therapy was superior to an information- and emotion-oriented approach in 1 study [142], but 2 other studies were neutral [129, 143].

CG education for coping skills in individual sessions was of particular success when conducted on CGs displaying psychological morbidity [134] or when an emotion-oriented approach was used [125]. A program focusing on family interactions [141] and an information-oriented program [125] failed to improve CG mood. The enrichment of CG education with other components (multicomponent intervention in the CG) also improved CG mood. For instance, after 6 months of intervention, the prevalence of clinical depression in CGs who received in-home education sessions and participated in a telephone support group was lower than that of CGs who only received minimal support (12.6 vs. $22.7 \%, \mathrm{p}=0.001$ ) [186].

In-home implementation of computer or telephone systems providing information and facilitating communication among family CGs (CG support, electronic devices) improved CG mood after 6-12 months of use. In a high-quality trial, a reduction in depressive symptoms and anxious complaints was demonstrated, but only in those CGs who reported low-mid level of life own control at baseline [161]. Age [162], relationship and ethnic characteristics [141] predicted response in other RCTs.

\section{NPTs to Improve CG PWB}

The PWB of the CG (either family or professional CG) was substantially improved after 8 or 10 weeks of cognitive stimulation in group sessions that were conducted on PWDs attending day centers or living in institutions. As for interventions more specifically targeted at CG PWB, only multicomponent interventions for the CG demonstrated benefits. For instance, a long-term program of counseling and continuous support improved the CG reaction to memory and behavior problems, satisfaction with social support and subjective burden, and these benefits mediated institutionalization delay [183].

\section{NPTs to Improve CG QoL}

Two highly individualized interventions built on comprehensive assessment of PWD and CG characteristics and needs (multicomponent interventions for PWD and CG, in-home counseling) improved CG QoL. One of these interventions, tested in a high-quality RCT, consisted of home visits by a case manager nurse and education and support groups for family CGs. After 6 months of intervention, an improvement in CG QoL was attained that persisted at the 12-month follow-up [208].

\section{NPTs to Avoid Restraints}

Professional CG training for alternatives to restraint avoided mechanical restraint, compared to usual care, in institutionalized PWDs. At the end of treatment, no differences were found in falls, mobility [220] and use of psychotropic drugs $[218,220]$ between experimental and control groups, although an increase in agitation was reported in the experimental group in one of the RCTs [218].

\section{Discussion}

This review provides a comprehensive assessment of nonpharmacological interventions in dementia building on previous reviews, but also extending the scope to all documented NPTs [224-227]. Most RCTs showed positive results, and solid (i.e. grade $\mathrm{A}$ or $\mathrm{B}$ ) recommendations could be established for most domains (fig. 3, table 2). Absence of a clear association between RCT quality and positive results suggests that publication bias would not on its own be an adequate explanation for the rates of intervention success (fig. 2). In order to obtain high-quality evidence, we used clearly specified and rigorous inclusion criteria, such as narrowing candidate studies to only 
RCTs documenting cognitive deterioration of degenerative etiology in all participants.

\section{Methodological Problems}

Despite the high number of RCTs included, the proportion of high-quality studies was low (fig. 2). Limitations such as often small and poorly defined samples may in part reflect the restricted financial support available for research of this kind. Other problems such as poorly specified interventions, absence of a theoretical model and lack of blind outcome measurements illustrate methodological difficulties commonly encountered in this research field. Our hope is that the growing number of lowquality RCTs lays the groundwork for and precedes a large cohort of high-quality RCTs in future years. Sometimes numerous outcome measures were used, and adjustments for multiple comparisons were lacking. In addition, most RCTs utilized usual care or minimal attention conditions as the control group. When experimental and control groups were exposed to similar social attention, positive results were less frequent, and intervention specificity became blurred (table 1). In addition, many studies did not have a clear theoretical model with a defined active agent intended to lead to a specific outcome. Instead, research has often been oriented towards the development and evaluation of multicomponent interventions for the PWD, CG or both and almost half of the findings and recommendations came from multicomponent categories, each category improving several domains. This means it is hard to know what element worked, how it worked and for whom.

\section{Key Findings}

Multicomponent interventions based on CG education and support delayed the institutionalization of ADRD persons (fig. 3) with only modest amounts of resources used. This important outcome in relation to both QoL and cost was not found with any other treatment approach on the basis of high-quality evidence. For other outcomes (cognition, ADLs, behavior, mood), the magnitude of the effect seemed to be similar to the effect obtained by drugs (table 2) [228]. Due to the general absence of side effects and since they can be more readily individualized, NPTs are preferable when particular ADLs or behaviors are targeted [229, 230]. Moreover, higher responsiveness to NPTs than to drugs should be expected for some other outcomes (QoL, CG psychological well-being, CG QoL). However, rather than being viewed as an alternative to medications, NPTs and drugs should be understood as complementary approaches [18, 19, 21, 45, 108, 109].

Nonpharmacological Therapies in AD
Some intervention categories (e.g. cognitive training, ADL training) related to specific benefits in the targeted domains whereas others (e.g. reminiscence, recreation therapy) may have more diffuse effects. NPTs lacking any recommendation were: transcutaneous electrical stimulation, physical exercise, use of music, reminiscence, massage and touch, recreation therapy, use of light, multisensory stimulation, support and psychotherapy, validation, case management and respite care. Problems included lack of studies, lack of adequate measures, poor design and insufficient duration of intervention.

Response predictors were extensively investigated in CG interventions $[133,134,159,161,183,227]$ but that was not the case for the studies of PWDs. Samples were frequently selected according to intervention aims (e.g. behaviorally disturbed persons for behavioral interventions), and response scales were similarly targeted. A large majority of participants in NPT studies were female, yet only 2 RCTs reported analyses according to the gender of the care receiver $[42,109]$. Some studies suggest that greater cognitive, functional and behavioral responses might be observed in less advanced dementia [231, 232], but these hypotheses were barely explored [212].

\section{Limitations}

The map and definitions of intervention categories and subcategories are open to future modifications, although they were developed and agreed upon by the expert consensus group, because of the complex and inconsistent nature of the interventions (particularly multicomponent). Although our methodology was rigorous, the need to achieve a comprehensive coverage meant that many low-quality RCTs were included with the inherent problem of bias in a number of areas. Hence, many of the RCTs included may not have met the methodological criteria for inclusion in Cochrane reviews. Cochrane reviews on cognitive stimulation and case management for dementia are currently in preparation, and we await these results with interest.

\section{Future Research}

Persons who were medically ill, sensorily impaired or nonnative language speakers, were usually excluded from studies, and interventions aimed at the even larger group of people with severe dementia were scarce. Specific programs should be carried out for these neglected groups. An emerging area of interest is the study of variables that may act as response mediators (i.e. variables that are amenable to modification as a result of the intervention and predict response). Some of these potential mediators (e.g.

Dement Geriatr Cogn Disord 2010;30:161-178 
CG distress) were included in the PWB domain; others (e.g. CG knowledge, attitudes and beliefs towards dementia) were outside the focus of the present review. Better understanding of response predictors and mediators will help in selecting and optimizing interventions according to individual settings, circumstances and needs $[154,183$, 199, 233]. Important challenges ahead concern research methodology: (a) interventions should be better described to facilitate replicability; (b) the lack of placebo (intervention and control conditions cannot be hidden) highlights the need for more elaborated blind assessment procedures; (c) the measurement of each component's dose and differential effects will gain importance due to their impact on the cost/benefit ratio; (d) contamination between study groups should be carefully addressed, and (e) motivation of the therapists could have an effect on results and should be accounted for. There is a clear need for further RCTs particularly in areas which are widely used, have a theoretical framework and can be clearly defined and provided at relatively low cost. In particular, high-quality large-scale RCTs are required in the areas of reminiscence, use of music and physical exercise.

Future studies could profitably compare different forms of intervention to elicit differential effects but, until the effects of interventions are better established, a usual-care comparison group is necessary. In addition, as illustrated in many head-to-head drug studies, comparing two active interventions is likely to reduce effect size leading to the need for much inflated sample sizes. In the early stages of an intervention, evaluation and development will be more modest, and less expensive designs (e.g. $\mathrm{n}=1$ trials, quasi-experimental trials) could precede RCTs or may need to be accepted as the only possible evidence to guide treatment of rare but very disruptive behavioral symptoms where RCTs cannot be performed due to sample size requirements. QoL and cost-related measures should be systematically added to the trials.

\section{Conclusion}

The results of this review indicate that NPTs can make both a realistic and affordable contribution to the improvement and provision of care for people with ADRD and their CGs. In contrast to drugs, nonpharmacological interventions are often of low cost, and the cost relates to human endeavor rather than expensive technology or medication. This means that NPTs of demonstrated effectiveness might be made available cheaply in developing countries. However, it also means that for business interests there is likely to be a relative lack of return on research investment in comparison with, say, a newly licensed medication. Governments, research charities and financially strong philanthropic organizations should make significant investments in the development and dissemination of NPTs to support research to improve the evidence for their effectiveness. The benefits to PWDs, their carers and society may be great, the investments comparatively modest and potential savings for the economy may be substantial.

\section{Acknowledgments}

The Fundación Maria Wolff financed small honoraria to I. Cruz for the documentation and classification of 1,313 studies screened for inclusion criteria, travel expenses of J. Olazarán and R. Muñiz for the design and conduct of the study, as well as minor materials needed. (The foundational objective of the Fundación Maria Wolff is to develop scientific projects in the treatment of dementia.) Dymphna Hermans (PhD) from the Cochrane Dementia and Cognitive Improvement Group provided intellectual and logistic support in the initial screening of RCTs (she received no compensation for her assistance in this paper).

\section{References}

1 Reisberg B, Javed A, Kenowsky S, Auer SR: Alzheimer's Disease; in Zaretsky HH, Richter EF III, Eisenberg MG (eds): Medical Aspects of Disability, ed 3. New York, Springer, 2005, pp 79-118.

2 Kitwood T: Dementia Reconsidered: The Person Comes First. Milton Keynes, Open University Press, 1997.

-3 Reisberg B, Franssen EH, Souren LE, Auer SR, Akram I, Kenowsky S: Evidence and mechanisms of retrogenesis in Alzheimer's and other dementias: management and treatment import. Am J Alzheimers Dis Other Demen 2002;17:202-212.
-4 Ferri CP, Prince M, Brayne C, Brodaty $\mathrm{H}$, Fratiglioni L, Ganguli M, Hall K, Hasegawa $\mathrm{K}$, Hendrie H, Huang Y, Jorm A, Mathers C, Menezes PR, Rimmer E, Scazufca M, for Alzheimer's Disease International: Global prevalence of dementia: a Delphi consensus study. Lancet 2005;366:2112-2117.

5 Wimo A, Winblad B, Jönsson L: An estimate of the total worldwide societal costs of dementia in 2005. Alzheimer Dementia 2007;3: 81-91.

- 6 Higgins JPT, Thompson SG, Deeks JJ, Altman DG: Measuring inconsistency in metaanalyses. BMJ 2003;327:557-560. 
7 Simon SD: Statistical Evidence in Medical Trials: Mountain or Molehill, What Do the Data Really Tell Us? New York, Oxford University Press, 2006.

$\checkmark 8$ Reisberg B, Ferris SH, de Leon MJ, Crook T: The Global Deterioration Scale for assessment of primary degenerative dementia. Am J Psychiatry 1982;139:1136-1139.

\9 Zarit SH, Zarit JM, Reever KE: Memory training for severe memory loss: effects on senile dementia patients and their caregivers. Gerontologist 1982;22:373-377.

$\checkmark 10$ Beck C, Heacock P, Mercer S, Thatcher R, Sparkman C: The impact of cognitive skills remediation training on persons with Alzheimer's disease or mixed dementia. J Geriatr Psychiatry 1988;21:73-88.

11 Günther V, Fuchs D, Schett P, Meise U, Rhomberg HP: Kognitives Training bei organischem Psychosyndrom (Cognitive training in psycho-organic syndromes). Dtsch Med Wochenschr 1991;116:846-851.

12 Heiss WD, Kessler J, Mielke R, Szelies B, Herholz K: Long-term effects of phophatidylserine, pyritinol and cognitive training in Alzheimer's disease. Dementia 1994;5:8898.

13 Quayhagen MP, Quayhagen M, Corbeil RR, Roth PA, Rodgers JA: A dyadic remediation program for care recipients with dementia. Nurs Res 1995;44:153-159.

14 Quayhagen MP, Quayhagen M, Corbeil RR, Hendrix RC, Jackson JE, Snyder L, et al: Coping with dementia: evaluation of four nonpharmacologic interventions. Int Psychogeriatr 2000;12:249-265.

15 Tappen RM, Roach KE, Applegate EB, Stowell P: Effect of a combined walking and conversation intervention on functional mobility of nursing home residents with Alzheimer disease. Alzheimer Dis Assoc Disord 2000;14:196-201.

16 Tappen RM, Williams CL, Barry C, Di Sesa D: Conversation intervention with Alzheimer's patients: increasing the relevance of communication. Clin Gerontol 2001;24:6375.

17 Davis RN, Massman PJ, Doody RS: Cognitive intervention in Alzheimer disease: a randomized placebo-controlled study. Alzheimer Dis Assoc Disord 2001;15:1-9.

18 Cahn-Weiner DA, Malloy PF, Rebok GW, Ott BR: Results of a randomized placebocontrolled study of memory training for mildly impaired Alzheimer's disease patients. Appl Neuropsychol 2003;10:215-223.

19 Loewenstein DA, Acevedo A, Czaja SJ, Duara R: Cognitive rehabilitation of mildly impaired Alzheimer disease patients on cholinesterase inhibitors. Am J Geriatr Psychiatry 2004;12:395-402.

20 Kawashima R, Okita K, Yamazaki R, Tajima N, Yoshida H, Taira M, et al: Reading aloud and arithmetic calculation improve frontal function of people with dementia. J Gerontol A Biol Sci Med Sci 2005;60A:380-384.
21 Tárraga L, Boada M, Modinos G, Espinosa A, Diego S, Morera A, Guitart M, Balcells J, Lopez OL, Becker JT: A randomised pilot study to assess the efficacy of an interactive, multimedia tool of cognitive stimulation in Alzheimer's disease. J Neurol Neurosurs Psychiatry 2006;77:1116-1121.

22 Galante E, Venturini G, Fiaccadori C: Computer-based cognitive intervention for dementia: preliminary results of a randomized clinical trial. G Ital Med Lav Ergon 2007;29: 26-32.

23 Rozzini L, Costardi D, Chilovi BV, Franzoni S, Trabucchi M, Padovani A: Efficacy of cognitive rehabilitation in patients with mild cognitive impairment treated with cholinesterase inhibitors. Int J Geriatr Psychiatry 2007;22:356-360.

24 Robinson K, Yates K: Effects of two caregiver-training programs on burden and attitude toward help. Arch Psychiatr Nurs 1994;8: 312-319.

25 Teri L, Logsdon RG, Uomoto J, McCurry SM: Behavioral treatment of depression in dementia patients: a controlled clinical trial. J Gerontol B Psychol Sci Soc Sci 1997;52:P159_ P166.

26 Burgener SC, Bakas T, Murray C, Dunahee J, Tossey S: Effective caregiving approaches for patients with Alzheimer's disease. Geriatr Nurs 1998;19:121-126.

27 Teri L, Logsdon RG, Peskind E, Raskind M Weiner MF, Tractenberg RE, et al: Treatment of agitation in $\mathrm{AD}$ : a randomized, placebocontrolled clinical trial. Neurology 2000;55: 1271-1278.

28 Gormley N, Lyons D, Howard R: Behavioural management of aggression in dementia: a randomized controlled trial. Age Ageing 2001;30:141-145.

29 Bourgeois, Michelle S, Schulz R, Burgio L, Beach S: Skills training for spouses of patients with Alzheimer's disease: outcomes of an intervention study. J Clin Geropsychol 2002;8:53-73.

30 Farran CJ, Gilley DW, McCann JJ, Bienias JL, Lindeman DA, Evans DA: Psychosocial interventions to reduce depressive symptoms of dementia caregivers: a randomized clinical trial comparing two approaches. J Mental Health Aging 2004;10:337-350.

31 Losada-Baltar A, Izal Fernandez de Troconiz M, Montorio Cerrato I, Marquez Gonzalez M, Perez Rojo G: Differential efficacy of two psychoeducational interventions for dementia family caregivers (in Spanish). Rev Neurol 2004;38:701-708.

32 Teri L, McCurry SM, Logsdon R, Gibbons LE: Training community consultants to help family members improve dementia care: a randomized controlled trial. Gerontologist 2005;45:802-811.

33 Gonyea JG, O'Connor MK, Boyle PA, Project CARE: A randomized controlled trial of a behavioral intervention group for Alzheimer's disease caregivers. Gerontologist 2006; $46: 827-832$.
34 Gant JR, Steffen AM, Lauderdale SA: Comparative outcomes of two distance-based interventions for male caregivers of family members with dementia. Am J Alzheimers Dis Other Demen 2007;22:120-128.

-35 Woods RT: Reality orientation and staff attention: a controlled study. Br J Psychiatry 1979;134:502-507.

36 Baines S, Saxby P, Ehlert K: Reality orientation and reminiscence therapy: a controlled cross-over study of elderly confused people. Br J Psychiatry 1987;151:222-231.

37 Gerber GJ, Prince PN, Snider HG, Atchinson K, Dubois L, Kilgour JA: Group activity and cognitive improvement among patients with Alzheimer's disease. Hosp Community Psychiatry 1991;42:843-846.

- 38 Breuil V, De Rotrou J, Forette F, Tortrar D, Ganancia-Ganem A, Frambourt A, et al: Cognitive stimulation of patients with dementia: preliminary results. Int J Geriatr Psychiatry 1994;9:211-217.

39 Robichaud L, Hebert R, Desrosiers J: Efficacy of a sensory integration program on behaviors of inpatients with dementia. Am J Occup Ther 1994;48:355-360.

40 Bach D, Bach M, Böhmer F, Frühwald T, Grilc B: Reactivating occupational therapy: a method to improve cognitive performance in geriatric patients. Age Ageing 1995;24:222-226.

-41 Spector A, Orrell M, Davies S, Woods B: Can reality orientation be rehabilitated? Development and piloting of an evidence-based programme of cognition-based therapies for people with dementia. Neuropsychol Rehabil 2001;11:377-397.

-42 Spector A, Thorgrimsen L, Woods B, Royan L, Davies S, Butterworth M, Orrell M: Efficacy of an evidence-based cognitive stimulation therapy programme for people with dementia. Br J Psychiatry 2003;183:248-254.

43 Knapp M, Thorgrimsen L, Patel A, et al: Cognitive stimulation therapy for people with dementia: cost-effectiveness analysis. Br J Psychiatry 2006; 188:574-580.

44 Politis AM, Vozzella S, Mayer LS, Onyike CU, Baker AS, Lyketsos CG: A randomized, controlled, clinical trial of activity therapy for apathy in patients with dementia residing in long-term care. Int J Geriatr Psychiatry 2004;19:1087-1094.

-45 Onder G, Zanetti O, Giacobini E, Frisoni GB, Bartorelli L, Carbones G, et al: Reality orientation therapy combined with cholinesterase inhibitors in Alzheimer's disease: randomized controlled trial. Br J Psychiatry 2005; 187:450-455.

46 Scherder EJ, Bouma A, Steen LM: Effects of 'isolated' transcutaneous electrical nerve stimulation on memory and affective behavior in patients with probable Alzheimer's disease. Biol Psychiatry 1998;43:417-424.

47 Van Someren EJW, Scherder EJA, Swaab DF: Transcutaneous electrical nerve stimulation (TENS) improves circadian rhythm disturbances in Alzheimer disease. Alzheimer Dis Assoc Disord 1998;12:114-118. 
48 Scherder EJ, Bouma A: Effects of transcutaneous electrical nerve stimulation on behavior and memory in Alzheimer's disease may be stage-dependent. Biol Psychiatry 1999;45: 743-749.

49 Scherder EJ, Van Someren EJ, Swaab DF: Transcutaneous electrical nerve stimulation (TENS) improves the rest-activity rhythm in midstage Alzheimer's disease. Behav Brain Res 1999;101:105-107.

-50 Scherder EJ, Deijen JB, Vreeswijk SH, Sergeant JA, Swaab DF: Cranial electrostimulation (CES) in patients with probable Alzheimer's disease. Behav Brain Res 2002;128: 215-217.

-51 Scherder E, Knol D, van Someren E, Deijen JB, Binnekade R, Tilders F, Sergeant J: Effects of low-frequency cranial electrostimulation on the rest-activity rhythm and salivary cortisol in Alzheimer's disease. Neurorehabil Neural Repair 2003;17:101-108.

-52 Luijpen MW, Swaab DF, Sergeant JA, Scherder EJ: Effects of transcutaneous electrical nerve stimulation (TENS) on self-efficacy and mood in elderly with mild cognitive impairment. Neurorehabil Neural Repair 2004; 18:166-175.

53 Luijpen MW, Swaab DF, Sergeant JA, van Dijk KR, Scherder EJ: Effects of transcutaneous electrical nerve stimulation (TENS) on memory in elderly with mild cognitive impairment. Behav Brain Res 2005;158:349357.

54 Van Dijk K, Scheltens P, Luijpen MW, Sergeant JA, Scherder E: Peripheral electrical stimulation in Alzheimer's disease. Dementia Geriatr Cogn Disord 2005;19:361-368.

$\checkmark 55$ Van Dijk KRA, Luijpen MW, Van Someren EJW, Sergeant JA, Scheltens P, Scherder EJA: Peripheral electrical nerve stimulation and rest-activity rhythm in Alzheimer's disease. J Sleep Res 2006;15:415-423.

-56 Scherder E, Knol D, van Tol MJ, van Someren E, Deijen JB, Swaab D, Scheltens P: Effects of high-frequency cranial electrostimulation on the rest-activity rhythm and salivary cortisol in Alzheimer's disease: a pilot study. Dement Geriatr Cogn Disord 2006;22:267-272.

57 Scherder EJ, van Tol MJ, Swaab DF: Highfrequency cranial electrostimulation (CES) in patients with probable Alzheimer's disease. Am J Phys Med Rehabil 2006;85:614618.

58 Scherder EJ, Vuijk PJ, Swaab DF, Van Someren EJ: Estimating the effects of right median nerve stimulation on memory in Alzheimer's disease: a randomized controlled pilot study. Exp Aging Res 2007;33:177-186.

-59 Friedman R, Tappen RM: The effect of planned walking on communication in Alzheimer's disease. J Am Geriatr Soc 1991; 39:650-654.

60 Francese T, Sorrell J, Butler FR: The effects of regular exercise on muscle strength and functional abilities of late stage Alzheimer's residents. Am J Alzheimer Dis 1997;12:122127.
61 Pomeroy VM, Warren CM, Honeycombe C, Briggs RS, Wilkinson DG, Pickering RM, et al: Mobility and dementia: is physiotherapy treatment during respite care effective? Int J Geriatr Psychiatry 1999;14:389-397.

62 Cott CA, Dawson P, Sidani S, Wells D: The effects of a walking/talking program on communication, ambulation, and functional status in residents with Alzheimer disease. Alzheimer Dis Assoc Disord 2002;16:81-87.

63 Toulotte C, Fabre C, Dangremont B, Lensel $\mathrm{G}$, Thevenon A: Effects of physical training on the physical capacity of frail, demented patients with a history of falling: a randomised controlled trial. Age Ageing 2003 32:67-73.

64 Scherder EJA, Van Paasschen J, Deijen J-B, Van der Knokke S, Orlebeke JFK, Burgers I, et al: Physical activity and executive functions in the elderly with mild cognitive impairment. Aging Mental Health 2005;9:272280.

65 Van Uffelen JG, Chin A, Hopman-Rock M, Van Mechelen W: The effect of walking and vitamin B supplementation on quality of life in community-dwelling adults with mild cognitive impairment: a randomized, controlled trial. Qual Life Res 2007;16:11371146

66 Van Uffelen JG, Chinapaw MJ, van Mechelen W, Hopman-Rock M: Walking or vitamin B for cognition in older adults with mild cognitive impairment? A randomised controlled trial. Br J Sports Med 2008;42:344-351.

67 Williams CL, Tappen RM: Effect of exercise on mood in nursing home residents with Alzheimer's disease. Am J Alzheimers Dis Other Demen 2007;22:389-397.

68 Riegler J: Comparison of a reality orientation program for geriatric patients with and without music. J Music Ther 1980;17:26-33.

69 Groene RW: Effectiveness of music therapy 1:1 intervention with individuals having senile dementia of the Alzheimer's type. J Music Ther 1993;30:138-157.

70 Lord TR, Garner JE: Effects of music on Alzheimer patients. Percept Mot Skills 1993; 76:451-455

71 Silber F: The influence of background music on the performance of the Mini-Mental State Examination with patients diagnosed with Alzheimer's disease. J Music Ther 1999;36: 196-206.

72 Remington R: Calming music and hand massage with agitated elderly. Nurs Res 2002;51:317-323.

73 Liu G, Yuan LX: Clinical observation on acupuncture combined with music for treatment of Alzheimer disease (in Chinese). Zhongguo Zhen Jiu 2005;25:390-392.

74 Svansdottir HB, Snaedal J: Music therapy in moderate and severe dementia of Alzheimer's type: a case-control study. Int Psychogeriatr 2006;18:613-621.
75 Tabourne CES: The effects of a life review program on disorientation, social interaction and self-esteem of nursing home residents. Int J Aging Hum Dev 1995;41:251266.

76 Thorgrimsen L, Schweitzer P, Orrell M: Evaluating reminiscence for people with dementia: a pilot study. Arts Psychother 2002; 29:93-97.

77 Lai CKY, Chi I, Kayser-Jones J: A randomized controlled trial of a specific reminiscence approach to promote the well-being of nursing home residents with dementia. Int Psychogeriatr 2004;16:33-49.

78 Haight BK, Gibson F, Michel Y: The Northern Ireland life review/life storybook project for people with dementia. Alzheimers Dement 2006;2:56-58.

79 Tadaka E, Kanagawa K: Effects of reminiscence group in elderly people with Alzheimer disease and vascular dementia in a community setting. Geriatr Gerontol Int 2007;7: 167-173.

80 Schnelle JF: Treatment of urinary incontinence in nursing home patients by prompted voiding. J Am Geriatr Soc 1990;38:356-360.

81 Tappen RM: The effect of skill training on functional abilities of nursing home residents with dementia. Res Nurs Health 1994; 17:159-165.

82 Coyne ML, Hoskins L: Improving eating behaviors in dementia using behavioral strategies. Clin Nurs Res 1997;6:275-290.

83 McGilton KS, Rivera TM, Dawson P: Can we help persons with dementia find their way in a new environment? Aging Ment Health 2003; 7:363-371.

84 Eaton M, Mitchell-Bonair IL, Friedmann E: The effect of touch on nutritional intake of chronic organic brain syndrome patients. J Gerontol 1986;41:611-616.

85 Woods DL, Craven RF, Whitney J: The effect of therapeutic touch on behavioral symptoms of persons with dementia. Altern Ther Health Med 2005;11:66-74.

86 Hawranik P, Johnston P, Deatrich J: Therapeutic touch and agitation in individuals with Alzheimer's disease. West J Nurs Res 2008;30:417-434

87 Mitchell LA, Maercklein G: The effect of individualized special instructions on the behaviors of nursing home residents diagnosed with dementia. Am J Alzheimer Dis Other Demen 1996;11:23-31.

88 Oppikofer S, Albrecht K, Schelling HR, Wettstein A: Die Auswirkungen sozialer Unterstützung auf das Wohlbefinden dementer Heimbewohnerinnen und Heimbewohner: die Käferberg-Besucherstudie (Effects of social support on the well-being of demented institutionalized aged). Z Gerontol Geriatrie 2002;35:39-48.

89 Richards KC, Beck C, O’Sullivan PS, Shue VM: Effect of individualized social activity on sleep in nursing home residents with dementia. J Am Geriatr Soc 2005;53:1510-1517. 
$\$ 90$ Ancoli-Israel S, Gehrman P, Martin JL, Shochat T, Marler M, Corey-Bloom J, Levi L: Increased light exposure consolidates sleep and strengthens circadian rhythms in severe Alzheimer's disease patients. Behav Sleep Med 2003;1:22-36.

-91 Ancoli-Israel S, Martin JL, Gehrman P, Shochat T, Corey-Bloom J, Marler M, et al: Effect of light on agitation in institutionalized patients with severe Alzheimer disease. Am J Geriatr Psychiatry 2003;11:194-203.

-92 Gasio PF, Krauchi K, Cajochen C, Someren E, Amrhein I, Pache M, Savaskan E, WirzJustice A: Dawn-dusk simulation light therapy of disturbed circadian rest-activity cycles in demented elderly. Exp Gerontol 2003;38:207-216.

93 Connell BR, Sanford JA, Lewis D: Therapeutic effects of an outdoor activity program on nursing home residents with dementia. J Hous Elderly 2007;21:195-209.

-94 Dowling GA, Burr RL, Van Someren EJ, et al: Melatonin and bright-light treatment for rest-activity disruption in institutionalized patients with Alzheimer's disease. J Am Geriatr Soc 2008;56:239-246.

-95 Baker R, Holloway J, Holtkamp CCM, Larsson A, Hartman LC, Pearce R, Scherman B, Johansson S, Thomas PW, Wareing LA, Owens M: Effects of multi-sensory stimulation for people with dementia. J Adv Nurs 2003;43:465-477.

96 Staal JA, Sacks A, Matheis R, Collier L, Calia T, Hanif H, Kofman ES: The effects of Snoezelen (multi-sensory behavior therapy) and psychiatric care on agitation, apathy, and activities of daily living in dementia patients on a short term geriatric psychiatric inpatient unit. Int J Psychiatry Med 2007;37:357-370.

97 Milev RV, Kellar T, McLean M, et al: Multisensory stimulation for elderly with dementia: a 24-week single-blind randomized controlled pilot study. Am J Alzheimers Dis Other Demen 2008;23:372-376.

98 La Barge E, Rosenman LS, Leavitt K, Cristiani T: Counseling clients with mild senile dementia of the Alzheimer's type: a pilot study. J Neurol Rehab 1988;2:167-173.

$\checkmark 99$ Burns A, Guthrie E, Marino-Francis F, et al: Brief psychotherapy in Alzheimer's disease: randomised controlled trial. Br J Psychiatry 2005; 187:143-147.

100 Robb S, Stegman CE, Wolanin MO: No research versus research with compromised results: a study of validation therapy. Nurs Res 1986;35:113-118.

-101 Toseland RW, Diehl M, Freeman K, Manzanares T, Naleppa M, McCallion P: The impact of validation group therapy on nursing home residents with dementia. J Appl Gerontol 1997;16:31-50.

102 Sun Y, Zhu P, Zhang M, Zhang Y: Clinical observation on Yuanluo Tongjing needling method for treatment of mild cognitive impairment (in Chinese). Zhongguo Zhenjiu 2007;27:810-812.
103 Solé-Padullés C, Bartrés-Faz D, Junqué C, et al: Repetitive transcranial magnetic stimulation effects on brain function and cognition among elders with memory dysfunction: a randomized sham-controlled study. Cereb Cortex 2006;16:1487-1493.

104 Suhr J, Anderson S, Tranel D: Progressive muscle relaxation in the management of behavioural disturbance in Alzheimer's disease. Neuropsychol Rehab 1999;9:31-44.

105 Koltai DC, Welsh-Bohmer KA, Schmechel DE: Influence of anosognosia on treatment outcome among dementia patients. Neuropsychol Rehab 2001;11:455-475.

106 Rapp SR, Brenes R, Marsh AP: Memory enhancement training for older adults with mild cognitive impairment: a preliminary study. Aging Mental Health 2002;6:5-11.

107 Teri L, Gibbons LE, McCurry SM, Logsdon RG, Buchner DM, Barlow WE, et al: Exercise plus behavioral management in patients with Alzheimer disease: a randomized controlled trial. JAMA 2003;290: 2015-2022.

108 Chapman SB, Weiner MF, Rackley A, Hynan LS, Zientz J: Effects of cognitivecommunication stimulation for Alzheimer's disease patients treated with donepezil. J Speech Lang Hear Res 2004;47:11491164.

109 Olazarán J, Muñiz R, Reisberg B, PeñaCasanova J, del Ser T, Cruz-Jentoft AJ, et al: Benefits of cognitive-motor intervention in MCI and mild to moderate Alzheimer disease. Neurology 2004;63:2348-2353.

110 Tadaka E, Kanagawa K: A randomized controlled trial of a group care program for community-dwelling elderly people with dementia. Jpn J Nurs Sci 2004;1:19-25.

111 Van de Winckel A, Fey H, De Weerdt W, Dom R: Cognitive and behavioural effects of music-based exercises in patients with dementia. Clin Rehabil 2004;18:253-260.

112 Jablonski RA, Reed D, Maas ML: Care intervention for older adults with Alzheimer's disease and related dementias: effect of family involvement on cognitive and functional outcomes in nursing homes. J Gerontol Nurs 2005;31:38-48.

113 McCurry SM, Gibbons LE, Logsdon RG, Vitiello MV, Teri L: Nighttime insomnia treatment and education for Alzheimer's disease: a randomized, controlled trial. J Am Geriatr Soc 2005;53:793-802.

114 Poon P, Hui E, Dai D, Kwok T, Woo J: Cognitive intervention for community-dwelling older persons with memory problems: telemedicine versus face-to-face treatment. Int J Geriatr Psychiatry 2005;20:285-286.

115 Stevens J, Killeen M: A randomised controlled trial testing the impact of exercise on cognitive symptoms and disability of residents with dementia. Contemp Nurse 2006;21:32-40.
116 Sung HC, Chang SM, Lee WL, Lee MS: The effects of group music with movement intervention on agitated behaviours of institutionalized elders with dementia in Taiwan. Complement Ther Med 2006;14:113-119.

117 Netz Y, Axelrad S, Argov E: Group physical activity for demented older adults feasibility and effectiveness. Clin Rehabil 2007;21: 977-986.

-118 Rolland Y, Pillard F, Klapouszczak A, Reynish E, Thomas D, Andrieu S, Riviere D, Vellas B: Exercise program for nursing home residents with Alzheimer's disease: a 1-year randomized, controlled trial. J Am Geriatr Soc 2007;55:158-165.

119 Burgener SC, Yang Y, Gilbert R, MarshYant S: The effects of a multimodal intervention on outcomes of persons with earlystage dementia. Am J Alzheimers Dis Other Demen 2008;23:382-394.

120 Meguro M, Kasai M, Akanuma K, Ishii H, Yamaguchi S, Meguro K: Comprehensive approach of donepezil and psychosocial interventions on cognitive function and quality of life for Alzheimer's disease: the OsakiTajiri Project. Age Ageing 2008;37:469-473.

121 Troyer AK, Murphy KJ, Anderson ND, Moscovitch M, Craik FI: Changing everyday memory behaviour in amnestic mild cognitive impairment: a randomised controlled trial. Neuropsychol Rehabil 2008; 18:65-88.

122 Zarit SH, Anthony CR, Boutselis M: Interventions with care givers of dementia patients: comparison of two approaches. Psychol Aging 1987;2:225-232.

123 Whitlatch CJ, Zarit SH, von Eye A: Efficacy of interventions with caregivers: a reanalysis. Gerontologist 1991;31:9-14.

124 Schmidt GL, Bonjean MJ, Wildem AC, Schefft BK, Steele DJ: Brief psychotherapy for caregivers of demented relatives: comparison of two therapeutic strategies. Clin Gerontologist 1988;7:109-125.

125 Sutcliffe C, Larner S: Counselling carers of the elderly at home: a preliminary study. $\mathrm{Br}$ J Clin Psychol 1988;27:177-178.

$>126$ Perkins RE, Poynton CF: Group counselling for relatives of hospitalized presenile dementia patients: a controlled study. Br J Clin Psychol 1990;29:287-295.

127 Hébert R, Leclerc G, Bravo G, Girouard D, Lefrançois R: Efficacy of a support group programme for care-givers of demented patients in the community: a randomized controlled trial. Arch Gerontol Geriatr 1994;18:1-14.

128 Hébert R, Girouard D, Leclerc G, Bravo G, Lefrançois R: The impact of a support group programme for care-givers on the institutionalisation of demented patients. Arch Gerontol Geriatr 1995;20:129-134.

129 Gendron C, Poitras L, Dastoor DP, Perodeau G: Cognitive-behavioral group intervention for spousal caregivers: findings and clinical considerations. Clin Gerontologist 1996;17:3-19. 
\$130 McCurry SM, Logsdon RG, Vitiello MV, Teri L: Successful behavioral treatment for reported sleep problems in elderly caregivers of dementia patients: a controlled study. J Gerontol B Psychol Sci Soc Sci 1998; 53:P122-P129.

-131 Ostwald SK, Hepburn KW, Caron W, Burns T, Mantell R: Reducing caregiver burden: a randomized psychoeducational intervention for caregivers of persons with dementia. Gerontologist 1999;39:299-309.

-132 Hepburn KW, Tornatore J, Center B, Ostwald SW: Dementia family caregiver training: affecting beliefs about caregiving and caregiver outcomes. J Am Geriatr Soc 2001; 49:450-457.

-133 Roberts J, Browne G, Milne C, Spooner L, Gafni A, Drummond-Young M, Le Gris J, Watt S, Le Clair K, Beaumont L, Roberts J: Problem-solving counseling for caregivers of the cognitively impaired: effective for whom? Nurs Res 1999;48:162-172.

-134 Marriott A, Donaldson C, Tarrier N, Burns A: Effectiveness of cognitive-behavioural family intervention in reducing the burden of care in carers of patients with Alzheimer's disease. Br J Psychiatry 2000;176:557-562.

135 Steffen AM: Anger management for dementia caregivers: a preliminary study using video and telephone interventions. Behav Ther 2000;31:281-299.

-136 Castro CM, Wilcox S, O’Sullivan P, Baumann K, King AC: An exercise program for women who are caring for relatives with dementia. Psychosom Med 2002;64:458-468.

- 137 King AC, Baumann K, O’Sullivan P, Wilcox S, Castro C: Effects of moderate-intensity exercise on physiological, behavioral, and emotional responses to family caregiving: a randomized controlled trial. J Gerontol A Biol Sci Med Sci 2002;57:M26-M36.

138 Fung W-Y, Chien W-T: The effectiveness of a mutual support group for family caregivers of a relative with dementia. Arch Psychiatr Nurs 2002;16:134-144.

-139 Burgio L, Stevens A, Guy D, Roth DL, Haley WE: Impact of two psychosocial interventions on white and African American family caregivers of individuals with dementia. Gerontologist 2003;43:568-579.

-140 Burns R, Nichols LO, Martindale-Adams J, Graney MJ, Lummus A: Primary care interventions for dementia caregivers: 2-year outcomes from the REACH study. Gerontologist 2003;43:547-555.

-141 Eisdorfer C, Szaja SJ, Loewenstein DA, Rubert MP, Argüelles S, Mitrani BV, et al: The effect of a family therapy and technologybased intervention on caregiver depression. Gerontologist 2003;43:521-531.

142 Gallagher-Thompson D, Coon DW, Solano N, Ambler C, Rabinowitz Y, Thompson LW: Change in indices of distress among Latino and Anglo female caregivers of elderly relatives with dementia: site-specific results from the REACH national collaborative study. Gerontologist 2003;43:580-591.
143 Hébert R, Levesque L, Vezina J, Lavoie JP, Ducharme F, Gendron C, Preville M, Voyer L, Dubois MF: Efficacy of a psychoeducative group program for caregivers of demented persons living at home: a randomized controlled trial. J Gerontol B Psychol Sci Soc Sci 2003;58:S58-S67.

144 Martin-Cook K, Remakel-Davis B, Svetlik D, Hynan LS, Weiner MF: Caregiver attribution and resentment in dementia care. Am J Alzheimers Dis Other Demen 2003; 18:366-374.

145 Akkerman RL, Ostwald SK: Reducing anxiety in Alzheimer's disease family caregivers: the effectiveness of a nine-week cognitive-behavioral intervention. Am J Alzheimers Dis Other Demen 2004;19:117-123.

146 Davis LL, Burgio LD, Buckwalter KC, Weaver M: A comparison of in-home and telephone-based skill training interventions with caregivers of persons with dementia. J Ment Health Aging 2004;10:3144.

147 Beauchamp N, Irvine AB, Seeley J, Johnson B: Worksite-based internet multimedia program for family caregivers of persons with dementia. Gerontologist 2005;45:793801.

148 Ducharme F, Lévesque L, Lachance. L, Giroux F, Legault A, Préville M: 'Taking Care of Myself': efficacy of an intervention programme for caregivers of a relative with dementia living in a long-term care setting. Int J Soc Res Pract 2005;4:23-47.

149 Ducharme F, Lévesque L, Giroux F, Lachance L: Follow-up of an intervention program for caregivers of a relative with dementia living in a long-term care setting: are there any persistent and delayed effects? Aging Ment Health 2005;9:461-469.

150 Hepburn KW, Lewis M, Narayan S, Center $\mathrm{B}$, Tornatore J, Bremer KL, et al: Partners in caregiving: a psychoeducation program affecting dementia family caregivers' distress and caregiving outlook. Clin Gerontol 2005;29:53-69.

151 Perren S, Schmid R, Wettstein A: Caregivers' adaptation to change: the impact of increasing impairment of persons suffering from dementia on their caregivers' subjective well-being. Aging and Mental Health 2006;10:539-548.

152 Gallagher-Thompson D, Gray HL, Tang PC, et al: Impact of in-home behavioral management versus telephone support to reduce depressive symptoms and perceived stress in Chinese caregivers: results of a pilot study. Am J Geriatr Psychiatry 2007;15: 425-434.

153 Hepburn K, Lewis M, Tornatore J, Sherman CW, Bremer KL: The Savvy Caregiver program: the demonstrated effectiveness of a transportable dementia caregiver psychoeducation program. J Gerontol Nurs 2007; $33: 30-36$.
154 Márquez-González M, Losada A, Izal M, Pérez-Rojo G, Montorio I: Modification of dysfunctional thoughts about caregiving in dementia family caregivers: description and outcomes of an intervention programme. Aging Ment Health 2007;11:616-625.

155 Ulstein ID, Sandvik L, Wyller TB, Engedal $\mathrm{K}$ : A one-year randomized controlled psychosocial intervention study among family carers of dementia patients - effects on patients and carers. Dement Geriatr Cogn Disord 2007;24:469-475.

156 Moniz-Cook E, Elston C, Gardiner E, et al: Can training community mental health nurses to support family carers reduce behavioural problems in dementia? An exploratory pragmatic randomised controlled trial. Int J Geriatr Psychiatry 2008;23:185-191.

157 Goodman CC, Pynoos J: A model telephone information and support program for caregivers of Alzheimer's patients. Gerontologist 1990;30:399-404.

158 Brennan PF, Moore SM, Smyth KA: The effects of a special computer network on caregivers of persons with Alzheimer's disease. Nurs Res 1995;44:166-172.

159 Bass DM, McClendon MJ, Brennan PF, McCarthy C: The buffering effect of a computer support network on caregiver strain. J Aging Health 1998;10:20-43.

160 Pillemer K, Suitor JJ: Peer support for Alzheimer's caregivers: is it enough to make a difference? Res Aging 2002;24:171-192.

161 Mahoney DF, Tarlow BJ, Jones RN: Effects of an automated telephone support system on caregiver burden and anxiety: findings from the REACH for TLC Intervention Study. Gerontologist 2003;43:556-567.

162 Winter L, Gitlin LN: Evaluation of a telephone-based support group intervention for female caregivers of community-dwelling individuals with dementia. Am J Alzheimers Dis Other Demen 2006;21:391-397.

163 Charlesworth G, Shepstone L, Wilson E, Thalanany M, Mugford M, Poland F: Does befriending by trained lay workers improve psychological well-being and quality of life for carers of people with dementia, and at what cost? A randomised controlled trial. Health Technol Assess 2008;12:1-78.

-164 Seltzer MM, Litchfield LC, Kapust LR, Mayer JB: Professional and family collaboration in case management: a hospitalbased replication of a community-based study. Soc Work Health Care 1992;17:1-22.

165 Weinberber M, Gold DT, Divine GW, Cowper PA, Hodgson LG, Schreiner PJ, et al: Social service interventions for caregivers of patients with dementia: impact on health care utilization and expenditures. J Am Geriatr Soc 1993;41:153-156.

166 Yordi C, Du Nah R, Bostrom A, Fox P, Wilkinson A, Newcomer R: Caregiver supports: outcomes from the Medicare Alzheimer's Disease Demonstration. Health Care Financ Rev 1997;19:97-117. 
167 Miller R, Newcomer R, Fox P: Effects of the Medicare Alzheimer's Disease Demonstration on nursing home entry. Health Serv Res 1999;34:691-714.

168 Newcomer R, Yordi C, Du Nah R, Fox P, Wilkinson A: Effects of the Medicare Alzheimer's Disease Demonstration on caregiver burden and depression. Health Serv Res 1999;34:669-689.

169 Newcomer R, Miller R, Clay T, Fox P: Effects of the Medicare Alzheimer's Disease Demonstration on Medicare expenditures. Health Care Financ Rev 1999;20:45-65.

- 170 Bass DM, Clark PA, Looman WJ, McCarthy CA, Eckert S: The Cleveland Alzheimer's managed care demonstration: outcomes after 12 months of implementation. Gerontologist 2003;43:73-85.

-171 Clark PA, Bass DM, Looman WJ, McCarthy CA, Eckert S: Outcomes for patients with dementia from the Cleveland Alzheimer's Managed Care Demonstration. Aging Ment Health 2004;8:40-51.

-172 Wishart L, Macerollo J, Loney P, King A, Beaumont L, Browne G, Roberts J: 'Special steps': an effective visiting/walking program for persons with cognitive impairment. Can J Nurs Res 2000;31:57-71.

-173 Grant I, McKibbin CL, Taylor MJ, Mills P, Dimsdale J, Ziegler M, Patterson TL: Inhome respite intervention reduces plasma epinephrine in stressed Alzheimer caregivers. Am J Geriatr Psychiatry 2003;11:62-72.

174 Lawton MP, Brody EM, Saperstein AR: A controlled study of respite service for caregivers of Alzheimer's patients. Gerontologist 1989;29:8-16.

- 175 Mohide EA, Pringle DM, Streiner DL, Gilbert JR, Muir G, Tew M: A randomized trial of family caregiver support in the home management of dementia. J Am Geriatr Soc 1990;38:446-454.

-176 Drummond MF, Mohide EA, Tew M, Streiner DL, Pringle DM, Gilbert JR: Economic evaluation of a support program for caregivers of demented elderly. Int J Technol Assess Health Care 1991;7:209-219.

- 177 Mittelman MS, Ferris SH, Steinberg G, Shulman E, Mackell JA, Ambinder A, Cohen J: An intervention that delays institutionalization of Alzheimer's disease patients: treatment of spouse-caregivers. Gerontologist 1993;33:730-740.

- 178 Mittelman MS, Ferris SH, Shulman E, Steinberg G, Ambinder A, Mackell JA, Cohen J: A comprehensive support program: effect on depression in spouse-caregivers of AD patients. Gerontologist 1995;35:792802.

179 Mittelman MS, Ferris SH, Shulman E, Steinberg G, Levin B: A family intervention to delay nursing home placement of patients with Alzheimer disease: a randomized controlled trial. JAMA 1996;276:17251731.
180 Mittelman MS, Roth DL, Haley WE, Zarit SH: Effects of a caregiver intervention on negative caregiver appraisals of behavior problems in patients with Alzheimer's disease: results of a randomized trial. J Gerontol B Psychol Sci Soc Sci 2004;59:P27-P34.

181 Mittelman MS, Roth DL, Coon DW, Haley WE: Sustained benefit of supportive intervention for depressive symptoms in caregivers of patients with Alzheimer's disease. Am J Psychiatry 2004;161:850-856.

182 Drentea P, Clay OJ, Roth DL, Mittelman MS: Predictors of improvement in social support: five-year effects of a structured intervention for caregivers of spouses with Alzheimer's disease. Soc Sci Med 2006;63: 957-967.

183 Mittelman MS, Haley WE, Clay OJ, Roth DL: Improving caregiver well-being delays nursing home placement of patients with Alzheimer disease. Neurology 2006;67: 1592-1599.

184 Mittelman MS, Roth DL, Clay OJ, Haley WE: Preserving health of Alzheimer caregivers: impact of a spouse caregiver intervention. Am J Geriatr Psychiatry 2007;15 780-789.

185 Gaugler JE, Roth DL, Haley WE, Mittelman MS: Can counseling and support reduce burden and depressive symptoms in caregivers of people with Alzheimer's disease during the transition to institutionalization? Results from the New York University Caregiver Intervention Study. J Am Geriatr Soc 2008;56:421-428.

186 Belle SH, Burgio L, Burns R, et al: Enhancing the quality of life of dementia caregivers from different ethnic or racial groups. Ann Intern Med 2006;145:727-738.

187 Nichols LO, Chang C, Lummus A, et al: The cost-effectiveness of a behavior intervention with caregivers of patients with Alzheimer's disease. J Am Geriatr Soc 2008;56: 413-420.

188 Finkel S, Czaja SJ, Schulz R, Martinovich Z, Harris C, Pezzuto D: E-care: a telecommunications technology intervention for family caregivers of dementia patients. Am J Geriatr Psychiatry 2007;15:443-448.

189 Buckwalter KC, Gerdner L, Kohout F, Hall GR, Kelly A, Richards B, Sime M: A nursing intervention to decrease depression in family caregivers of persons with dementia. Arch Psychiatr Nurs 1999;13:80-88.

190 Gerdner LA, Buckwalter KC, Reed D: Impact of a psychoeducational intervention on caregiver response to behavioral problems. Nurs Res 2002;51:363-374.

191 Stolley JM, Reed D, Buckwalter KC: Caregiving appraisal and interventions based on the progressively lowered stress threshold model. Am J Alzheimers Dis Other Demen 2002;17:110-120.

192 Chang BL: Cognitive-behavioral intervention for homebound caregivers of persons with dementia. Nurs Res 1999;48:173-181.
193 McCallion P, Toseland RW, Freeman K: An evaluation of a family visit education program. J Am Geriatr Soc 1999;47:203-214.

194 Chu P, Edwards J, Levin J, Thompson J: The use of clinical case management for early stage Alzheimer's patients and their families. Am J Alzheimers Dis Other Demen 2000;15:284-292.

195 Gitlin LN, Corcoran M, Winter L, Boyce A, Hauck WW: A randomized, controlled trial of a home environmental intervention: effect on efficacy and upset in caregivers and on daily function of persons with dementia. Gerontologist 2001;41:4-14.

196 Garand L, Buckwalter KC, Lubaroff D, Tripp-Reimer T, Frantz RA, Ansley TN: A pilot study of immune and mood outcomes of a community-based intervention for dementia caregivers: the PLST intervention. Arch Psychiatr Nurs 2002;16:156-167.

197 Gitlin LN, Winter L, Corcoran M, Dennis MP, Schinfeld S, Hauck WW: Effects of the home environmental skill-building program on the caregiver-care recipient dyad: 6-month outcomes from the Philadelphia REACH Initiative. Gerontologist 2003;43: 532-546.

198 Gitlin LN, Hauck WW, Dennis MP, Winter L: Maintenance of effects of the home environmental skill-building program for family caregivers and individuals with Alzheimer's disease and related disorders. J Gerontol A Biol Sci Med Sci 2005;60:368374.

199 HilgemanMM, Allen RS, De Coster J, Burgio LD: Positive aspects of caregiving as a moderator of treatment outcome over 12 months. Psychol Aging 2007;22:361-371.

200 Nobili A, Riva E, Tettamanti M, Lucca U, Liscio M, Petrucci B, Porro GS: The effect of a structured intervention on caregivers of patients with dementia and problem behaviors: a randomized controlled pilot study. Alzheimer Dis Assoc Disord 2004; 18:75-82.

201 Bottino CM, Carvalho IA, Alvarez AM, Avila R, Zukauskas PR, Bustamante SE, Andrade FC, Hototian SR, Saffi F, Camargo $\mathrm{CH}$ : Cognitive rehabilitation combined with drug treatment in Alzheimer's disease patients: a pilot study. Clin Rehabil 2005;19: 861-869.

202 Martin-Cook K, Davis BA, Hynan LS, Weiner MF: A randomized, controlled study of an Alzheimer's caregiver skills training program. Am J Alzheimers Dis Other Demen 2005;20:204-210.

-203 Graff MJ, Vernooij-Dassen MJ, Thijssen M, Dekker J, Hoefnagels WH, Rikkert MG: Community based occupational therapy for patients with dementia and their caregivers: randomised controlled trial. BMJ 2006;333:1196. 
204 Graff MJ, Vernooij-Dassen MJ, Thijssen M, Dekker J, Hoefnagels WH, Olderikkert MG: Effects of community occupational therapy on quality of life, mood, and health status in dementia patients and their caregivers: a randomized controlled trial. J Gerontol A Biol Sci Med Sci 2007;62:10021009.

-205 Graff MJL, Adang EMM, Vernooij-Dassen MJM, Dekker J, Jonsson L, Thijssen M, Hoefnagels WHL, Olde Rikkert MGM: Community occupational therapy for older patients with dementia and their caregivers: cost-effectiveness study. BMJ 2008;336: 134-138.

206 Logsdon RG, McCurry SM, Teri L: Timelimited support groups for individuals with early stage dementia and their care partners: preliminary outcomes from a controlled clinical trial. Clin Gerontol 2006;30: 5-19.

-207 Stocking CB, Hougham GW, Danner DD, Patterson MB, Whitehouse PJ, Sachs GA: Empirical assessment of a research advance directive for persons with dementia and their proxies. J Am Geriatr Soc 2007;55: 1609-1612.

208 Chien W, Lee Y: A disease management program for families of persons in Hong Kong with dementia. Psychiatr Serv 2008; 59:433-436

209 Gitlin LN, Winter L, Burke J, Chernett N, Dennis MP, Hauck WW: Tailored activities to manage neuropsychiatric behaviors in persons with dementia and reduce caregiver burden: a randomized pilot study. Am J Geriatr Psychiatry 2008;16:229-239.

-210 McCallion P, Toseland RW, Lacey D, Banks $\mathrm{S}$ : Educating nursing assistants to communicate more effectively with nursing home residents with dementia. Gerontologist 1999:39:546-558.

-211 Finnema E, de Lange J, Dröes RM, Ribbe M, van Tilburg W: The quality of nursing home care: do the opinions of family members change after implementation of emotion-oriented care? J Adv Nurs 2001;35: 728-740.

-212 Finnema E, Dröes RM, Ettema T, Ooms M, Adèr H, Ribbe M, van Tilburg W: The effect of integrated emotion-oriented care versus usual care on elderly persons with dementia in the nursing home and on nursing assistants: a randomized clinical trial. Int J Geriatr Psychiatry 2005;20:330-343.
213 Richardson B, Kitchen G, Livingston G: The effect of education on knowledge and management of elder abuse: a randomized controlled trial. Age Aging 2002;31:335341.

214 Schrijnemaekers V, van Rossum E, Candel M, Frederiks C, Derix M, Sielhorst H, van den Brandt P: Effects of emotion-oriented care on elderly people with cognitive impairment and behavioral problems. Int Geriatr Psychiatry 2002;17:926-937.

215 Schrijnemaekers VJ, Van Rossum E, Candel MJ, Frederiks CM, Derix MM, Sielhorst $\mathrm{H}$, van den Brandt PA: Effects of emotionoriented care on work-related outcomes of professional caregivers in homes for elderly persons. J Gerontol B Psychol Sci Soc Sci 2003;58:S50-S57.

216 Kovach CR, Taneli Y, Dohearty P, Schlidt AM, Cashin S, Silva-Smith AL: Effect of the BACE intervention on agitation of people with dementia. Gerontologist 2004;44:797806.

217 Teri L, Huda P, Gibbons L, Young H, van Leynseele J: STAR: a dementia-specific training program for staff in assisted living residences. Gerontologist 2005;45:686693

218 Testad I, Aasland AM, Aarsland D: The effect of staff training on the use of restraint in dementia: a single-blind randomised controlled trial. Int J Geriatr Psychiatry 2005;20:587-590.

219 Hoeffer B, Talerico KA, Rasin J, Mitchell CM, Stewart BJ, McKenzie D, et al: Assisting cognitively impaired nursing home residents with bathing: effects of two bathing interventions on caregiving. Gerontologist 2006; 46:524-532.

220 Huizing AR, Hamers JPH, Gulpers MJM Berger MPF: Short-term effects of an educational intervention on physical restraint use: a cluster randomized trial. BMC Geriatrics 2006;6:17.

221 Robison J, Curry L, Gruman C, Porter M, Henderson CR, Pillemer K: Partners in caregiving in a special care environment: cooperative communication between staff and families on dementia units. Gerontologist 2007;47:504-515.
222 Wells Y, Jorm AF: Evaluation of a special nursing home unit for dementia sufferers: a randomized controlled comparison with community care. Aust NZ J Psychiatry 1987;21:524-531.

223 Rosen WG, Mohs RC, Davis KL: A new rating scale for Alzheimer's disease. Am J Psychiatry 1984;141:1356-1364.

224 American Psychiatric Association. Practice guideline for the treatment of patients with Alzheimer's disease and other dementias of late life. Am J Psychiatry 1997;154(suppl): 1-39.

225 Doody RS, Stevens JC, Beck C, Dubinsky RM, Kaye JA, Gwyther L, et al: Practice parameter: management of dementia (an evidence-based review). Report of the Quality Standards Subcommittee of the American Academy of Neurology. Neurology 2001;56: 1154-1166.

226 Brodaty H, Green A, Koschera A: Metaanalysis of psychosocial interventions for caregivers of people with dementia. J Am Geriatr Soc 2003;51:657-664.

227 Livingston G, Johnston K, Katona C, Paton J, Lyketsos CG, Old Age Task Force of the World Federation of Biological Psychiatry: Systematic review of psychological approaches to the management of neuropsychiatric symptoms of dementia. Am J Psychiatry 2005;162:1996-2021.

228 Luijpen MW, Scherder EJA, Van Someren EJW, Swaab DF, Sergeant JA: Non-pharmacological interventions in cognitively impaired and demented patients: a comparison with cholinesterase inhibitors. Rev Neurosci 2003;14:343-368.

229 Bourgeois MS, Burgio LD, Schulz R, Beach S, Palmer B: Modifying repetitive verbalizations of community-dwelling patients with AD. Gerontologist 1997;37:30-39.

230 Bird M: Behavioural difficulties and cued recall of adaptative behaviour in dementia: experimental and clinical evidence. Neuropsychol Rehab 2001;11:357-375.

231 Bäckman L: Memory training and memory improvement in Alzheimer's disease: rules and exceptions. Acta Neurol Scand Suppl 1992;139:84-89.

-232 McEvoy CL, Patterson RL: Behavioral treatment of deficit skills in dementia patients. Gerontologist 1986;26:475-478.

233 Woods B, Thorgrimsen L, Spector A, Royan L, Orrell M: Improved quality of life and cognitive stimulation therapy in dementia. Aging Mental Health 2006;10:219-226. 